\title{
Distribution of terrigenous lipids in marine sediments off northeastern Taiwan
}

\author{
Woei-Lih Jeng ${ }^{\mathrm{a}, *}$, Saulwood Lin ${ }^{\mathrm{a}}$, Shuh-Ji Kao ${ }^{\mathrm{b}}$ \\ a Institute of Oceanography, National Taiwan University, Taipei, Taiwan, ROC \\ ${ }^{\mathrm{b}}$ Institute of Earth Sciences, Academia Sinica, Taipei, Taiwan, ROC
}

Received 12 December 2002

\begin{abstract}
Surface sediments on the continental margin off northeastern Taiwan have been analyzed for terrigenous lipids including $n$-alkanes, $n$-fatty alcohols, and sterols. Marine input to the sediments is particularly low based on the average $n-\mathrm{C}_{17} / n-\mathrm{C}_{29}$ alkane and $n-\mathrm{C}_{16} / n-\mathrm{C}_{28}$ fatty alcohol ratios, $0.15 \pm 0.13$ and $0.13 \pm 0.06$, respectively; this may be due to the fact that marine lipids are more prone to degradation than terrestrial ones. The study area has the highest plant wax $n$ alkane contribution (average carbon preference index 3.9 \pm 1.2 ) among the coastal marine areas surrounding Taiwan; lateral particle transport from the southern East China Sea shelf and river runoff from the east Taiwan coast are considered to be the major contributors. The distributions of plant wax $n$-alkane and $n$-alkanol concentrations normalized to total organic carbon (TOC) in the study area generally show maximum values on the upper slope of the southernmost Okinawa Trough, but not for phytosterols. Linear regression of TOC versus plant wax $n$-alkane concentrations show a weak relationship $(r=0.64, p=0.001)$, and an even weaker relationship $(r=0.42, p=0.05)$ between TOC and plant wax $n$-fatty alcohol concentrations is found. This could be attributed to several factors: (1) a complex input (not a point source) of terrigenous organic matter to the study area, (2) TOC also including marine organic matter, (3) temporal variations in river flow due to flooding, and (4) different rates of degradation for TOC and individual biomarkers. However, in spite of those factors, TOC and phytosterol concentrations are positively linearly correlated $(r=0.85, p<0.001)$, implying that the dilution of phytosterols in terrigenous organic carbon with marine organic carbon with or without the phytosterols follows a nearly constant ratio, which is remarkable. In addition, the predominant source of diploptene in the sediments does not appear to be of higher plant origin.
\end{abstract}

(C) 2003 Elsevier Science Ltd. All rights reserved.

\section{Introduction}

Hydrocarbon distribution as indicators of source matter identification has been an important and useful tool in organic geochemistry studies. In general, biomarkers for higher plants can be found

\footnotetext{
*Corresponding author. Fax: 886-2-23626092.

E-mail address: wljeng@oc.ntu.edu.tw (W.-L. Jeng).
}

in most continental shelf sediments. For instance, $n$-alkanes in marine sediments that show an odd carbon number predominance in the $n-\mathrm{C}_{25}-n-\mathrm{C}_{35}$ region indicate a contribution from land sources (Gearing et al., 1976; Farrington and Tripp, 1977; Keizer et al., 1978; Jeng, 1984). Higher plant waxes tend to contain mainly longer-chain $\left(>\mathrm{C}_{22}\right)$ saturated alcohols (Eglinton and Hamilton, 1963, 1967; Kolattukudy, 1970; Tulloch, 1976). 
Therefore, longer-chain alcohols also have been used commonly as higher-plant markers in sediments (Cranwell, 1984; Volkman et al., 1987). However, in areas of higher productivity, terrigenous biomarkers are less abundant than marine biomarkers. As an example, Smith et al. (1983) reported that a marine sediment taken from the Peru continental shelf showed a larger contribution from marine sources (probably mainly from phytoplankton and bacteria) and little terrigenous influence. Campesterol, stigmasterol and $\beta$-sitosterol are the three common phytosterols generally found in epicuticular waxes of vascular plants (Scheuer, 1973; Weete, 1976; Wannigama et al., 1981), and are normally considered to be higherplant input to sediments (Gagosian et al., 1983; Shaw and Johns, 1985). However, $\mathrm{C}_{29}$ sterols also could originate from marine organisms such as certain microalgae and perhaps cyanobacteria (Volkman, 1986).

Huang and Meinschein (1976) have shown that the $\%$ composition of cholesterol increases as the $\%$ composition of $\beta$-sitosterol decreases in the sample sequence of river inlet sediments-bay sediments - Gulf sediments - bay and Gulf plankton. Calculations based on the sterol ratios gave the percent of the sterols in the Gulf sediments derived from terrigenous sources. Lee et al. (1979) observed a decrease in sterol contents seaward in the sediments collected (farther east of the SEEP sampling locations) in the Atlantic Ocean, and concluded that part of the sterols in the slope sediments originate from terrigenous debris.

For the transport of organic matter from the land to the sea, organic geochemical analyses of benthic sediments from a Northern Queensland (Australia) coastal transect indicated that most terrestrial organic material is confined to nearshore sediments (less than $10 \mathrm{~km}$ offshore) (Currie and Johns, 1989). For the transport on the continental margin, Venkatesan et al. (1987) examined the lipid fraction in six sediment cores collected from the Atlantic shelf, slope and the rise areas, and found that the concentrations of organic compound classes decreased from the shelf through the slope to the rise, and estimated that about $50 \%$ of the shelf organic matter is exported to the slope. Similar results were also obtained for sediments from the continental shelf south of New England (Venkatesan et al., 1988). In general, the terrestrial component of the organic matter in unconsolidated sediments decreases progressively offshore, but this is not so on the Scotian margin (Canada) where organic matter with the greatest marine input is found in inshore basins (Pocklington et al., 1991).

Lin et al. (1992) investigated the organic carbon content in the continental margin sediments off northeastern Taiwan and found that lowest organic carbon concentrations were found in the shelf sediments while high concentrations were observed in the upper continental slope sediments. Chen et al. (1992) studying the composition and texture of surface sediments off northeastern Taiwan concluded that in the Okinawa Trough the sediments beneath the path of the main Kuroshio flow are composed of non-biogenic, fined-grain mud.

The circulation patterns of the seas off northeastern Taiwan have been given elsewhere (Hsu et al., 1998). Briefly, the Kuroshio Current flows northward along the east coast of Taiwan. Its subsurface water shoals up off the northeast coast and turns northeastward along the East China Sea continental slope. The inputs of terrigenous organic matter to this area are rather complexfrom the northwest and south together with the runoff of the Lan-yang River. In order to examine the influence of high river flow and the Kuroshio Current on the lipid and organic carbon distributions in this area, $n$-alkanes, $n$-fatty alcohols and sterols in the sediments were analyzed to determine terrestrial lipid distribution and contribution to this area and its relation to organic carbon, which can provide important information for understanding carbon budget.

\section{Materials and methods}

Samples were collected on the continental margin off northeastern Taiwan using a box corer on cruises ORI-417 (April 24-May 1, 1995) and ORI-456 (July 6-12, 1996). A total of 23 box core sediments were collected, and sample locations are given in Table 1 . Surface sediments (top $3-5 \mathrm{~cm}$ 
Table 1

Sampling locations off northeastern Taiwan

\begin{tabular}{llll}
\hline Station & Latitude $(\mathrm{N})$ & Longitude $(\mathrm{E})$ & Water depth $(\mathrm{m})$ \\
\hline ORI-417 & & & \\
5 & $24^{\circ} 50.18^{\prime}$ & $122^{\circ} 49.08^{\prime}$ & 1522 \\
8 & $25^{\circ} 00.97^{\prime}$ & $122^{\circ} 30.84^{\prime}$ & 1438 \\
9 & $24^{\circ} 59.44^{\prime}$ & $122^{\circ} 40.24^{\prime}$ & 1465 \\
10 & $25^{\circ} 00.17^{\prime}$ & $122^{\circ} 50.16^{\prime}$ & 1518 \\
16 & $25^{\circ} 11.35^{\prime}$ & $122^{\circ} 30.88^{\prime}$ & 894 \\
20 & $25^{\circ} 01.59^{\prime}$ & $122^{\circ} 18.03^{\prime}$ & 1096 \\
21 & $24^{\circ} 45.32^{\prime}$ & $122^{\circ} 22.57^{\prime}$ & 1115 \\
27 & $25^{\circ} 46.13^{\prime}$ & $123^{\circ} 07.08^{\prime}$ & 118 \\
34 & $24^{\circ} 39.91^{\prime}$ & $122^{\circ} 30.08^{\prime}$ & 462 \\
36 & $24^{\circ} 30.57^{\prime}$ & $122^{\circ} 20.7^{\prime}$ & 542 \\
37 & $24^{\circ} 30.18^{\prime}$ & $122^{\circ} 12.22^{\prime}$ & 404 \\
42 & $25^{\circ} 31.06^{\prime}$ & $123^{\circ} 03.77^{\prime}$ & 805 \\
43 & $25^{\circ} 18.59$ & $123^{\circ} 00.51^{\prime}$ & 1360 \\
44 & $25^{\circ} 15.12^{\prime}$ & $122^{\circ} 52.10^{\prime}$ & 1465 \\
45 & $25^{\circ} 06.15^{\prime}$ & $122^{\circ} 48.25^{\prime}$ & 1526 \\
46 & $24^{\circ} 50.09^{\prime}$ & $123^{\circ} 00.12^{\prime}$ & 1665 \\
& & & \\
ORI-456 & & & \\
27 & $25^{\circ} 33.88^{\prime}$ & $122^{\circ} 36.72^{\prime}$ & 887 \\
33 & $25^{\circ} 13.94^{\prime}$ & $122^{\circ} 34.96^{\prime}$ & 911 \\
34 & $25^{\circ} 22.28^{\prime}$ & $122^{\circ} 25.15^{\prime}$ & 451 \\
35 & $25^{\circ} 31.86^{\prime}$ & $122^{\circ} 14.98^{\prime}$ & 117 \\
37 & $25^{\circ} 11.93^{\prime}$ & $122^{\circ} 07.99^{\prime}$ & 156 \\
39 & $24^{\circ} 49.93^{\prime}$ & $122^{\circ} 08.04^{\prime}$ & 612 \\
$\mathrm{~K}$ & $25^{\circ} 30.97^{\prime}$ & $122^{\circ} 50.98^{\prime}$ & 1211 \\
\hline & & & \\
\hline
\end{tabular}

from subcores) were individually analyzed. Sediment samples were freeze-dried. After adding internal standards $\left(n-\mathrm{C}_{24} \mathrm{D}_{50}\right.$ and 1-heptadecanol), sediment samples were extracted with a mixture of benzene and methanol $(1: 1, \mathrm{v} / \mathrm{v})$ for $24 \mathrm{~h}$ in a Soxhlet apparatus. The lipid extract was then saponified by reflux for $3 \mathrm{~h}$ with $0.5 \mathrm{~N} \mathrm{KOH}$ solution in methanol. The non-saponifiable lipids were isolated by hexane extraction four times and concentrated using $\mathrm{N}_{2}$ gas. Aliphatic hydrocarbons and the fatty alcohols and sterols containing fraction were isolated from the neutral lipids by silica gel (deactivated with $5 \% \mathrm{H}_{2} \mathrm{O}$ ) column chromatography using hexane and a mixture of dichloromethane/methanol $(4 / 1, \mathrm{v} / \mathrm{v})$, respectively. The lipids between the two fractions were eluted with hexane/dichloromethane $(2 / 3, \mathrm{v} / \mathrm{v})$ and discarded. The isolated alcohols and sterols were taken to dryness, redissolved in benzene, and derivatized with N,O-bis(trimethylsilyl)acetamide. For gas chromatography (GC) analysis, an HP
5890 gas chromatograph equipped with a split/ splitless injector and a flame ionization detector (FID) was used. An SGE (Australia) OCI-5 cool on-column injector also was fitted in the gas chromatograph for quantitation. Separation of aliphatic hydrocarbons was achieved on an SPB-1 capillary column $(30 \mathrm{~m} \times 0.25 \mathrm{~mm}$ i.d. $)$, and that of alkanols/sterols (as TMS ethers) was accomplished by another SPB-1 column $(25 \mathrm{~m} \times 0.25 \mathrm{~mm}$ i.d. $)$. Oven-temperature programming was $45-90^{\circ} \mathrm{C}$ at $15^{\circ} \mathrm{C} / \mathrm{min}$ and $90-270^{\circ} \mathrm{C}$ at $3^{\circ} \mathrm{C} / \mathrm{min}$ for analyzing aliphatic hydrocarbons, and $45-90^{\circ} \mathrm{C}$ at $15^{\circ} \mathrm{C} / \mathrm{min}$ and $90-250^{\circ} \mathrm{C}$ at $3^{\circ} \mathrm{C} / \mathrm{min}, 30 \mathrm{~min}$ at $250^{\circ} \mathrm{C}$ for analyzing alkanols/sterols. Identification was made with co-injection of authentic standards and gas chromatography-mass spectrometry (GC-MS). The GC-MS analyses were performed with an HP 6890 GC (HP-1MS crosslinked methyl siloxane column, $30 \mathrm{~m} \times 0.25 \mathrm{~mm}$ i.d.) interfaced directly to an HP 5973 quadruple mass selective detector (electron impact, electron energy $70 \mathrm{eV}$, scanned from 50 to $550 \mathrm{D}$ ). Based on replicate analyses by GC-FID, the analytical precision of lipids was calculated to be $2-8 \%$.

Organic carbon was analyzed using infrared determination of $\mathrm{CO}_{2}$ evolved from high temperature $\left(1400^{\circ} \mathrm{C}\right)$ combustion with a LECO SC-444 carbon/sulfur analyzer. Approximately $0.25 \mathrm{~g}$ of dry sediment was pre-acidified with $\sim 2 \mathrm{ml}$ of $6 \mathrm{~N}$ $\mathrm{HCl}$ to remove carbonate carbon. After drying on a hot-plate for $8 \mathrm{~h}$ at $\sim 60^{\circ} \mathrm{C}$, the sample was combusted in a LECO carbon analyzer to measure its organic carbon content. The LECO carbon standard (502-062) was used for calibration. The average analytical precision was $0.88 \%$ (1 s.d.).

\section{Results and discussion}

\subsection{Terrestrial lipid contribution and distribution}

Gas chromatograms of aliphatic hydrocarbons in the study area show a minor unresolved complex mixture (UCM) (Fig. 1), suggesting some input from petroleum or biodegradation sources (Brassell and Eglinton, 1980) or from eroded hydrocarbons. In addition, it is noted that the lower molecular weight region $\left(<\mathrm{C}_{23}\right)$ has a $\mathrm{CPI}$ 


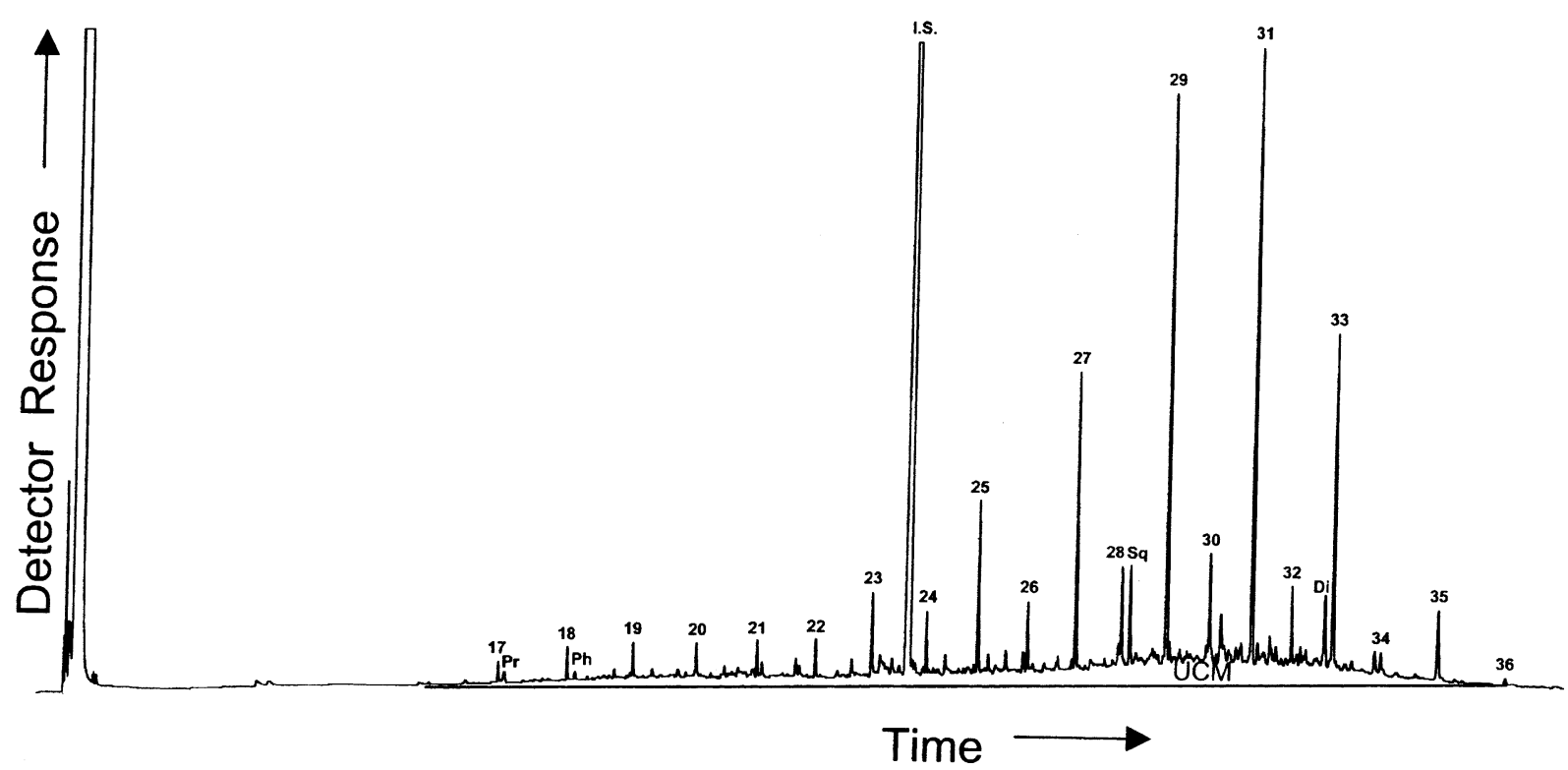

Fig. 1. Gas chromatogram of aliphatic hydrocarbons from station 456-37. Numbers above the peaks refer to carbon number of $n$ alkanes; $\mathrm{Pr}=$ pristane; $\mathrm{Ph}=$ phytane; $\mathrm{Sq}=$ squalene; $\mathrm{Di}=$ diploptene; $\mathrm{UCM}=$ unresolved complex mixture.

of 0.99 , possibly indicating a contribution from fossil fuels. As shown in Fig. 2, mass chromatograms of characteristic ions $m / e$ 85, 191, and 217 illustrate the distribution of alkanes, triterpanes and steranes, respectively. For pentacyclic triterpanes ( $m / e$ 191), besides diploptene, two compounds cannot be unequivocally identified from mass spectra that are similar to those of lupane and oleanane. Sterane $(m / e$ 217) characteristic ions are of very low intensity, and no steranes were found. In addition, generally there were no lowmolecular-weight ( $\leqslant 3$ aromatic rings) polycyclic aromatic hydrocarbons (PAHs) along with their alkylated homologues found in the sediments, nor were high-molecular-weight ( $\geqslant 4$ aromatic rings) parental (non-alkylated) PAH compounds found. This result indicates probably lack of fossil fuels and their combustion products in the sediments. However, there was one predominant PAHperylene found (Fig. 3; Table 2), which is considered to be derived from diagenesis (Venkatesan, 1988). For instance, a down-core increase of perylene concentrations $(191,311,388,514,629$, $542 \mathrm{ng} / \mathrm{g}$, each section being $4 \mathrm{~cm}$ ) was observed in a box core taken from station 417-20, reflecting transformation from unknown natural precursors
(Louda and Baker, 1984). From the above results, it can be concluded that the study area is considered to have minimal contamination by hydrocarbons related to petroleum.

The sediments have predominantly $n-\mathrm{C}_{25}, n-\mathrm{C}_{27}$, $n-\mathrm{C}_{29}, n-\mathrm{C}_{31}$ and $n-\mathrm{C}_{33}$ paraffins, typical of terrestrial plant waxes (Eglinton and Hamilton, 1967), and a unimodal distribution having a maximum at $\mathrm{C}_{31}$ (the abundance order $n-\mathrm{C}_{25}<n$ $\mathrm{C}_{27}<n-\mathrm{C}_{29}<n-\mathrm{C}_{31}$ ). In comparison, the $n$-alkane profiles of the Changjiang estuary sediments exhibit a bimodal distribution with the first maximum at $n-\mathrm{C}_{31}$ and the second maximum at $n-\mathrm{C}_{17}$ or other lower molecular weight $\left(<n-\mathrm{C}_{23}\right) n$ alkanes (Bigot et al., 1990). The common feature of these two areas is the $n-\mathrm{C}_{31}$ maximum. The major $n$-alkanes found in marine phytoplankton (Blumer et al., 1971), benthic algae (Youngblood et al., 1971), and pelagic Sargassum (Burns and Teal, 1973) are $n-\mathrm{C}_{15}$ and $n-\mathrm{C}_{17}$, which are present in only small amounts in the sedimentary $n$ alkanes of this area. The ratio of $n-\mathrm{C}_{17} / n-\mathrm{C}_{29}$ was employed by Venkatesan et al. (1987) as a parameter to indicate marine vs. terrigenous input of $n$-alkanes; this ratio in the 23 samples examined has a wide range of $0.00-0.31$ with a mean of 


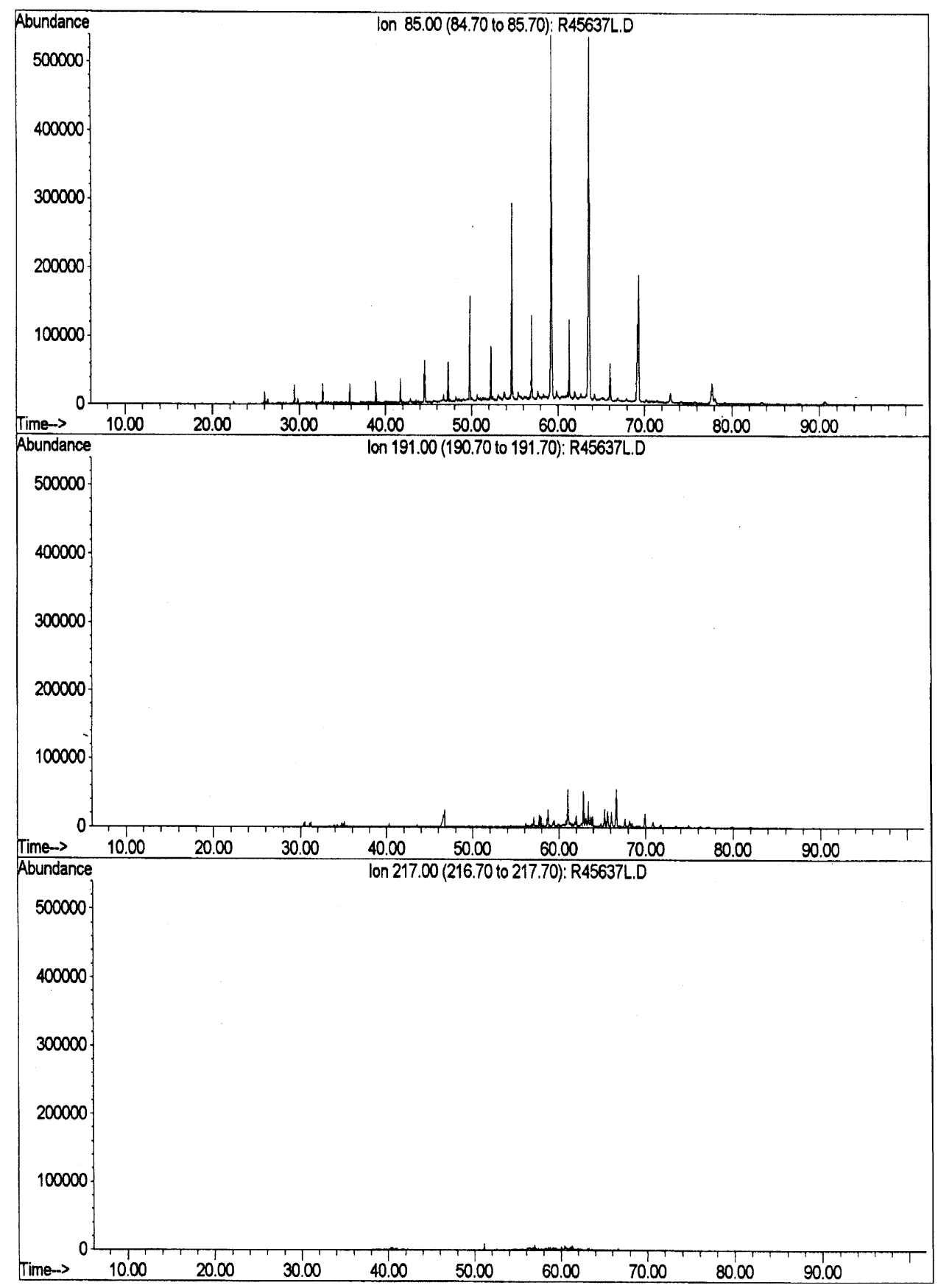

Fig. 2. Specific ion plots for $m / e 85$ (alkanes), 191 (triterpanes), and 217 (steranes) from the GC-MS analysis of the aliphatic fraction from station 456-37. 


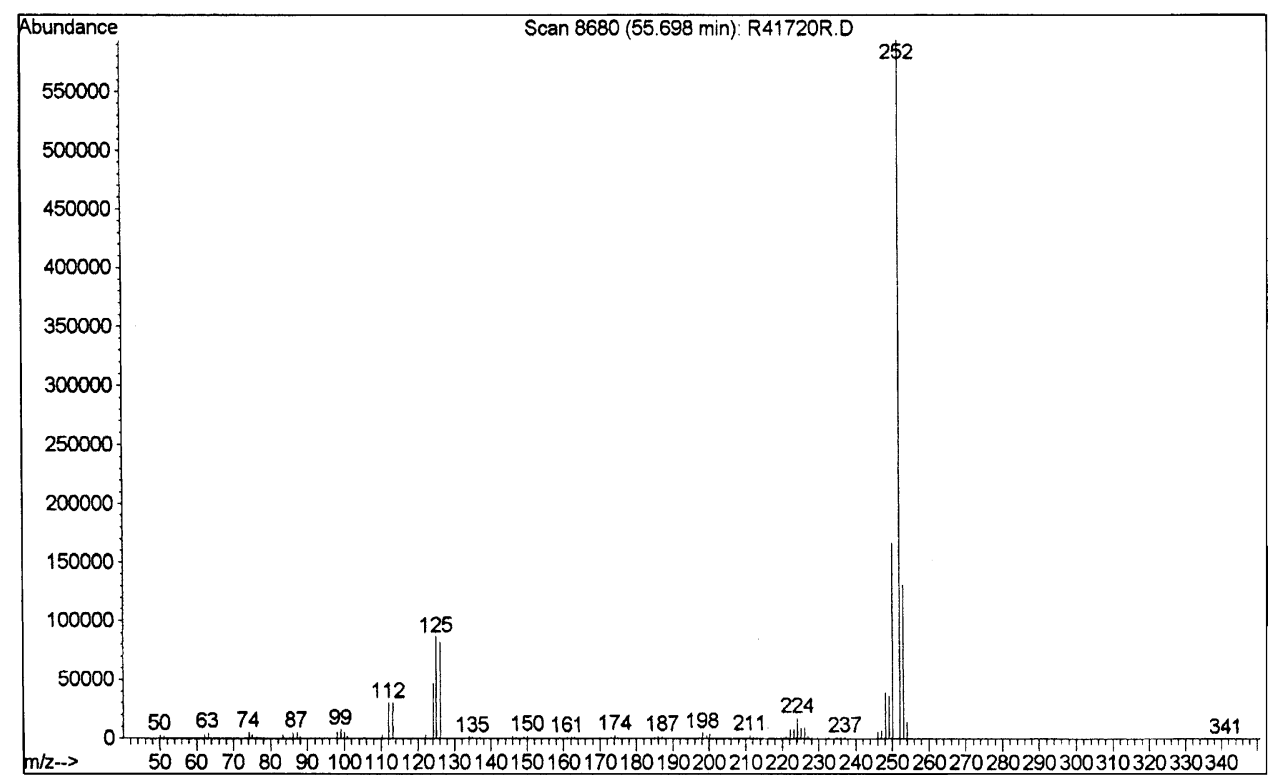

Fig. 3. Electron impact mass spectrum of perylene from station 417-20.

$0.15 \pm 0.13$ (Table 2). Two surficial sediments with a low level of contamination from the Changjiang estuary and adjacent East China Sea have $n-\mathrm{C}_{17} / n$ $\mathrm{C}_{29}$ ratios of 0.20 and 0.60 (calculated from histograms given by Bigot et al., 1990). The ratio in the suspended particles from surface waters of the Changjiang has an average of $0.33 \pm 0.18$ ( $n=13$, calculated from $n$-alkane concentrations given by Sicre et al., 1993). Surface sediments $(0-10 \mathrm{~cm})$ on the Amazon shelf have a mean $n-\mathrm{C}_{17} /$ $n-\mathrm{C}_{29}$ ratio of 0.38 (six values being $0.23,0.33$, $0.37,0.39,0.41$ and 0.57 calculated from histograms given by Elias and Cardoso, 1996). Two sediment core sections (20-40 and 40-60 cm) from the Bering Sea have the $n-\mathrm{C}_{17} / n-\mathrm{C}_{29}$ ratio of 0.26 and 0.59 (calculated from the peak heights of GC traces given by Kennicutt et al., 1991). One surface sediment from the Bellingshausen Sea, Antarctica has a $n-\mathrm{C}_{17} / n-\mathrm{C}_{29}$ ratio of 0.80 (calculated from histogram given by Cripps, 1995). The ratio for sediments from southeast Florida is 6.68 (reef track), 10.26 (Hawk Channel), 2.54 (nearshore Atlantic), 0.46 (bay), and 4.15 (ABC channel) (calculated from data given by Snedaker et al., 1995). The top $1 \mathrm{~cm}$ sediment from the middle Black Sea has a $n-\mathrm{C}_{17} / n-\mathrm{C}_{29}$ ratio of 0.09 (calculated from data given by Wakeham, 1996).
For our samples, the ratio is apparently at the low end; this can probably be attributed to (1) the predominance of the terrestrial $n$-alkane contribution to the coastal marine sediments, and (2) preferential degradation of marine-derived $n$ alkanes relative to terrigenous $n$-alkanes (Prahl et al., 1980; Meyers et al., 1984).

To compare with other marine sediments surrounding Taiwan, another parameter is used. Land plant $n$-alkane contribution to marine sediments is often expressed as carbon preference index, (CPI). Compared with the CPIs of northern and southern Taiwan Strait surface sediments and eastern Taiwan shelf (ca. $1-20 \mathrm{~km}$ in width) sediments, 2.0, 1.7 and 2.3, respectively (Jeng, $1978,1979,1984)$, the average CPI value of the study area is relatively high, $3.88 \pm 1.16$ (Table 2) indicating a strong terrestrial $n$-alkane influence. A similar index for higher plant wax contribution to marine sediments is odd-even predominance (OEP) proposed by Scalan and Smith (1970) as a means of reducing the mathematical limitations of the CPI. The Mackenzie River is regarded as providing a homogeneous, well-defined terrigenous input of $n$-alkanes to the Mackenzie shelf (Yunker et al., 1991). Five OEP $\mathrm{C}_{29}$ ratios for Mackenzie shelf (Beaufort Sea) sediments are 2.20, 
Table 2

Hydrocarbon data

\begin{tabular}{|c|c|c|c|c|c|c|c|c|c|}
\hline Sample & $\begin{array}{l}\text { TOC } \\
\left(10^{-2} \mathrm{~g} / \mathrm{g}\right)\end{array}$ & $\begin{array}{l}n-\mathrm{C}_{17} \\
(\mathrm{ng} / \mathrm{g})\end{array}$ & $\begin{array}{l}n-\mathrm{C}_{29} \\
(\mathrm{ng} / \mathrm{g})\end{array}$ & $n-\mathrm{C}_{17} / n-\mathrm{C}_{29}$ & $\begin{array}{l}\sum n-\mathrm{C}_{25-33} \\
(\mathrm{ng} / \mathrm{g})\end{array}$ & $\begin{array}{l}\left(\sum n-\mathrm{C}_{25-33} /\right. \\
\text { TOC }) \times 10^{-7}\end{array}$ & $\begin{array}{l}\mathrm{CPI}^{\mathrm{a}} \& \\
\mathrm{OEP}^{\mathrm{b}}\end{array}$ & $\begin{array}{l}\text { Diploptene } \\
(\mathrm{ng} / \mathrm{g})\end{array}$ & $\begin{array}{l}\text { Perylene } \\
(\mathrm{ng} / \mathrm{g})\end{array}$ \\
\hline \multicolumn{10}{|l|}{$O R I-417$} \\
\hline $5(0-5 \mathrm{~cm})$ & 1.01 & 95 & 467 & 0.20 & 1820 & 1800 & $2.61 / 2.62$ & 1140 & n.d. ${ }^{\mathrm{c}}$ \\
\hline $8(0-3 \mathrm{~cm})$ & 1.05 & 108 & 509 & 0.21 & 1970 & 1880 & $2.54 / 2.40$ & 2020 & n.d. \\
\hline $9(0-3 \mathrm{~cm})$ & 1.09 & 113 & 439 & 0.26 & 1760 & 1610 & $2.49 / 2.27$ & 518 & 151 \\
\hline $10(0-3 \mathrm{~cm})$ & 1.00 & 10 & 439 & 0.02 & 1690 & 1690 & $2.60 / 2.50$ & 530 & n.d. \\
\hline $16(0-5 \mathrm{~cm})$ & 0.82 & n.d. & 394 & - & 1640 & 2000 & $3.47 / 3.35$ & 169 & 157 \\
\hline $20(0-4 \mathrm{~cm})$ & 0.63 & 32 & 691 & 0.05 & 2450 & 3880 & $6.06 / 5.27$ & 42 & 191 \\
\hline $21(0-4 \mathrm{~cm})$ & 0.77 & 222 & 418 & 0.53 & 1630 & 2110 & $2.81 / 2.76$ & 433 & 118 \\
\hline 27 & 0.16 & 1 & 57 & 0.02 & 208 & 1300 & $5.49 / 5.55$ & 10 & 31 \\
\hline $34(0-4 \mathrm{~cm})$ & 0.69 & 32 & 731 & 0.04 & 2620 & 3800 & $5.24 / 5.21$ & 29 & 740 \\
\hline $36(0-4 \mathrm{~cm})$ & 0.42 & 51 & 502 & 0.01 & 1870 & 4450 & $5.76 / 5.69$ & 37 & 124 \\
\hline $37(0-4 \mathrm{~cm})$ & 0.29 & 17 & 91 & 0.19 & 358 & 1230 & $3.17 / 3.46$ & 9 & n.d. \\
\hline $42(0-4 \mathrm{~cm})$ & 0.41 & 51 & 154 & 0.33 & 581 & 1420 & $3.82 / 4.24$ & 32 & 24 \\
\hline $43(0-4 \mathrm{~cm})$ & 0.73 & 8 & 288 & 0.03 & 1090 & 1500 & $3.69 / 3.50$ & 182 & 86 \\
\hline $44(0-4 \mathrm{~cm})$ & 0.84 & 84 & 378 & 0.24 & 1460 & 1940 & $3.34 / 3.27$ & 303 & 102 \\
\hline 45 & 0.87 & 58 & 380 & 0.15 & 1470 & 1690 & $3.23 / 3.16$ & 529 & 155 \\
\hline $46(0-4 \mathrm{~cm})$ & 0.79 & 59 & 335 & 0.18 & 1300 & 1650 & $3.83 / 3.86$ & 533 & 204 \\
\hline \multicolumn{10}{|l|}{$O R I-456$} \\
\hline 27 & 0.74 & 27 & 784 & 0.03 & 2150 & 1910 & $5.17 / 4.69$ & 92 & n.d. \\
\hline $33(0-4 \mathrm{~cm})$ & 0.38 & n.d. & 177 & - & 552 & 1450 & $4.17 / 3.90$ & 70 & n.d. \\
\hline $34(0-4 \mathrm{~cm})$ & 0.74 & n.d. & 827 & - & 3000 & 4050 & $5.91 / 5.54$ & 74 & n.d. \\
\hline 35 & 0.14 & 3 & 43 & 0.07 & 135 & 964 & $4.13 / 4.24$ & 15 & n.d. \\
\hline 37 & 0.36 & 11 & 341 & 0.03 & 998 & 2770 & $3.19 / 3.03$ & 37 & n.d. \\
\hline $39(0-4 \mathrm{~cm})$ & 0.71 & 59 & 477 & 0.12 & 1140 & 1610 & $3.19 / 3.14$ & 176 & n.d. \\
\hline $\mathrm{K}(0-4 \mathrm{~cm})$ & 0.60 & 62 & 252 & 0.25 & 763 & 1270 & $3.22 / 2.95$ & 205 & n.d. \\
\hline Average & & & & 0.15 & & & $3.88 / 3.77$ & & \\
\hline s.d. $(1 \sigma)$ & & & & 0.13 & & & $1.16 / 1.09$ & & \\
\hline
\end{tabular}

${ }^{\mathrm{a}}$ Carbon preference index $=\frac{1}{2}\left(\frac{n \mathrm{C}_{25}+n \mathrm{C}_{27}+n \mathrm{C}_{29}+n \mathrm{C}_{31}+n \mathrm{C}_{33}}{n \mathrm{C}_{24}+n \mathrm{C}_{26}+n \mathrm{C}_{28}+n \mathrm{C}_{30}+n \mathrm{C}_{32}}+\frac{n \mathrm{C}_{25}+n \mathrm{C}_{27}+n \mathrm{C}_{29}+n \mathrm{C}_{31}+n \mathrm{C}_{33}}{n \mathrm{C}_{26}+n \mathrm{C}_{28}+n \mathrm{C}_{30}+n \mathrm{C}_{32}+n \mathrm{C}_{34}}\right)$.

b odd even predominance $n-\mathrm{C}_{29}$ ratio $=\left(n-\mathrm{C}_{27}+6 n-\mathrm{C}_{29}+n-\mathrm{C}_{31}\right) /\left(4 n-\mathrm{C}_{28}+4 n-\mathrm{C}_{30}\right)$.

${ }^{\mathrm{c}}$ n.d. $=$ not determined.

2.18, 2.11, 3.14 and 4.28 (Yunker et al., 1993), with a mean of 2.78. The average of our OEP $\mathrm{C}_{29}$ ratios is $3.77 \pm 1.09$ (Table 2). The difference could be due to stronger terrigenous $n$-alkane influence in the study area or difference in $n$-alkane maximum $-\mathrm{C}_{31}$ for the study area and $\mathrm{C}_{29}$ for the Mackenzie shelf.

Several factors can account for this interesting result of high land plant $n$-alkane inputs to the study area. The most important one is that shorter-chain alkanes, such as $n-\mathrm{C}_{17}$, are more prone to degradation than longer-chain $n$-alkanes.
Second, a part of the study area is a region with comparatively high sedimentation rates around Taiwan (Hung and Chung, 1994; Chung and Chang, 1995); this tends to create a reducing environment, especially on the upper slope (e.g., mottled and filamented authigenic pyrite has been found by Chen et al., 1995), which is favorable for preserving organic matter. Third, suspended particulates in runoff of other rivers on the eastern coast carried by the Kuroshio Current presumably tend to be deposited in the southern part of the study area. 
Prior to discussing the distribution of lipid data, it is advantageous to know the nearby river flow and predominant ocean currents. The inputs of terrigenous organic matter to the study area are rather complex-from the northwest and south together with the runoff of the Lan-yang River (Fig. 4). A small alongshore flow just off north Taiwan may carry materials from the southern East China Sea and Taiwan Strait (west of Taiwan) to this area (arrow 1). Contribution of materials from the Lan-yang River runoff is apparent (arrow 2). Another source is other river runoffs from eastern Taiwan carried by the Kuroshio Current to the study area (arrow 3). Their respective contributions of terrigenous lipids to this area will be compared in the following discussion.

In coastal regions receiving predominantly detrital input of organic material essentially from a point source, plant wax $n$-alkane concentrations normalized to TOC show a general decrease with distance offshore, e.g., Washington State, USA (Prahl and Carpenter, 1984). The trend can be attributed to dilution of the biomarkers in terrestrial organic carbon, with an increasing proportion of marine organic carbon containing none of the terrestrial $n$-alkanes. The spatial distribution of land plant derived $n$-alkanes (sum of $n-\mathrm{C}_{25}, n-\mathrm{C}_{27}, n-\mathrm{C}_{29}, n-\mathrm{C}_{31}$ and $n-\mathrm{C}_{33}$ ) normalized to TOC (to eliminate the grain size effect) is given

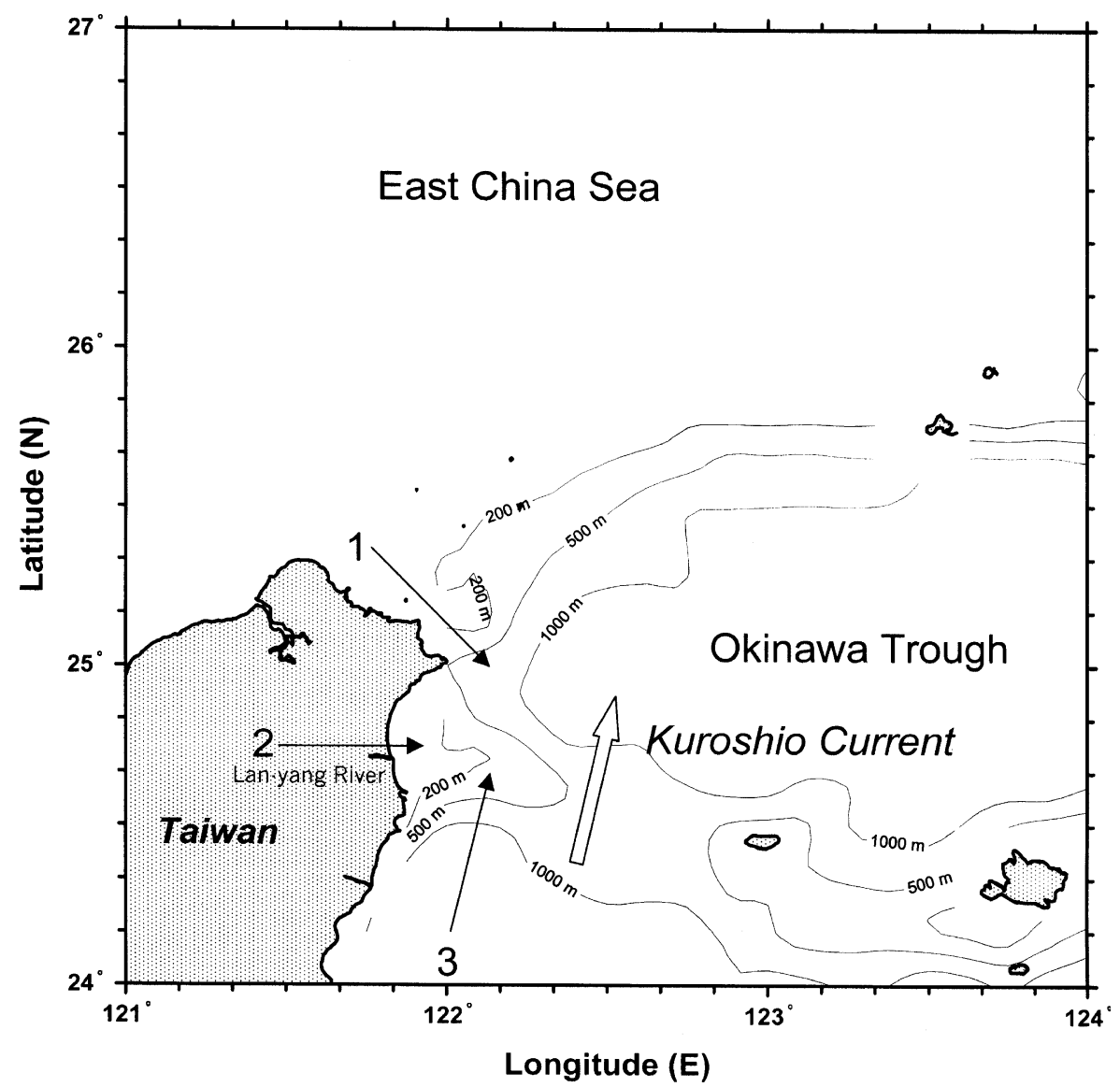

Fig. 4. Map showing river inputs and ocean currents in the study area. Arrow 1: A small alongshore flow just off north Taiwan carrying materials from the southern East China Sea and Taiwan Strait (west of Taiwan) to the study area. Arrow 2: Direct inputs of terrigenous materials from the Lan-yang River. Arrow 3: Other river runoffs from eastern Taiwan carried by the Kuroshio Current to the study area. 
in Fig. 5. The major distribution features are that (1) the westernmost four stations in the study area have low values, (2) the four stations with highest values are on the upper slope (shown in solid squares) near Taiwan, and (3) the stations on the lower slope show low values. The distribution suggests a major terrestrial contribution of $n$ alkanes to the area from Taiwan. This is supported by the fact that the immediate shelf north of the study area has no net deposition. For instance, we have collected six other surface sediments (located from $120^{\circ} 10^{\prime} \mathrm{E}$ to $123^{\circ} \mathrm{E}$ and from $25^{\circ} 40^{\prime} \mathrm{N}$ to $25^{\circ} 50^{\prime} \mathrm{N}$ ) from the immediate shelf area and have found that the samples contain shell debris and have low concentrations of mud (0.03-0.77\%).
Further, the Keelung shelf offshore northern Taiwan exhibits a rocky bottom with sparsely scattered sandy sediments. These facts suggest that the adjacent shelf has little sediment for export to the study area. However, three sediment-trap moorings deployed in the canyon located between the two highest values of plant wax $n$-alkanes normalized to TOC stations (Fig. 5) in the north have been shown to have high apparent mass fluxes, 5-72 $\mathrm{gm}^{-2} \mathrm{~d}^{-1}$ (Hung and Chung, 1998). The particle flux could result from a combined flow of an anticyclonic eddy (whose center located at $122^{\circ} 35^{\prime} \mathrm{E}, 25^{\circ} 20^{\prime} \mathrm{N}$, details given by Tang et al., 1999) and a southeastward filament (a small alongshore flow) occasionally appearing some-

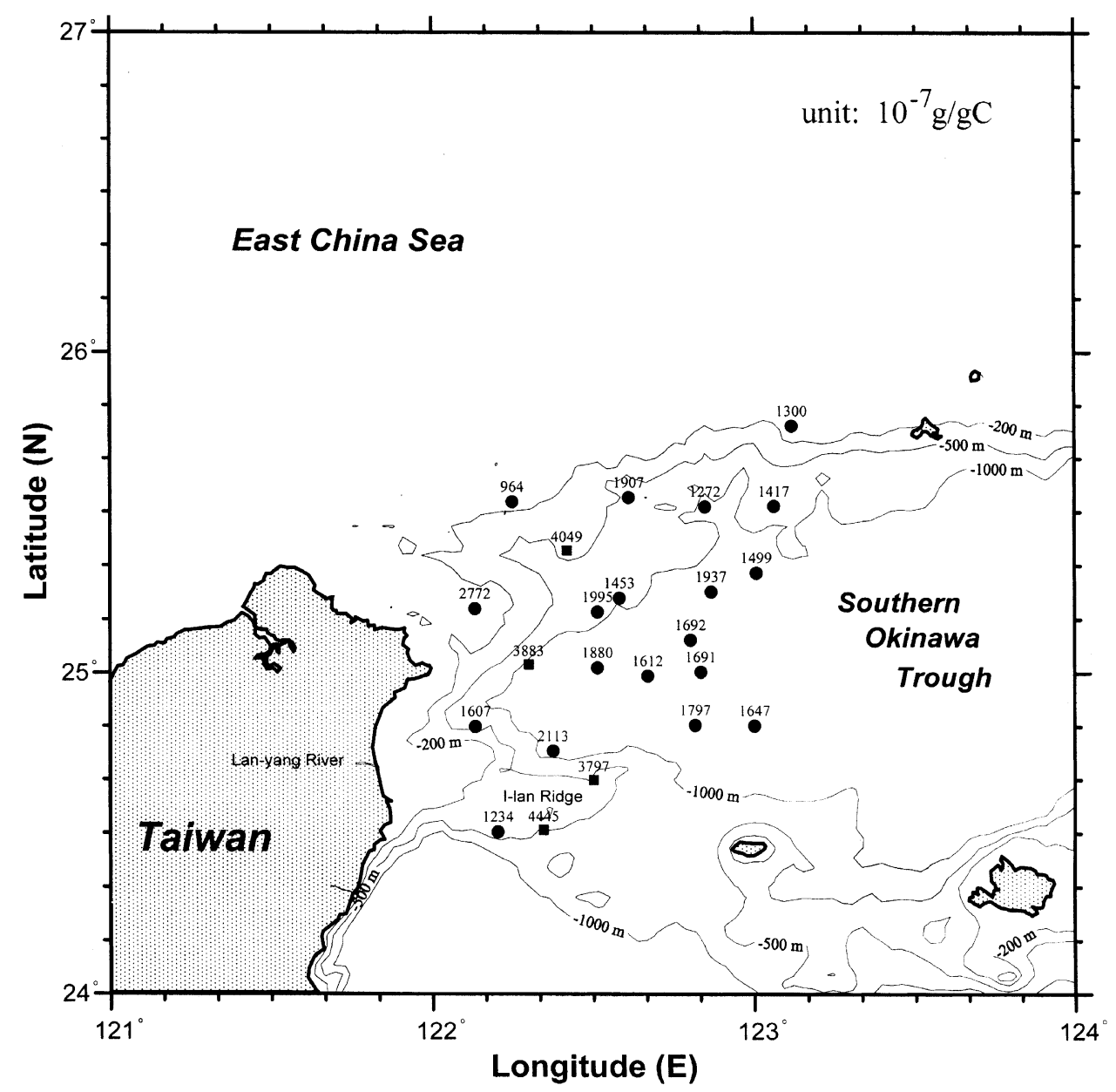

Fig. 5. Spatial distribution of plant wax $n$-alkanes $\left(n-\mathrm{C}_{25}+n-\mathrm{C}_{27}+n-\mathrm{C}_{29}+n-\mathrm{C}_{31}+n-\mathrm{C}_{33}\right)$ normalized to TOC. 
where between the eddy and northern Taiwan (Chern et al., 1990). This suggests that the major mode of sediment transport is suspended particle flow from the southern East China Sea continental shelf. Another possible contribution to this area (particularly the two highest stations in the south) could be the deposition of particles carried by the northbound Kuroshio Current from the south.

For better illustration of terrigenous $n$-alkane distribution, CPI is used because it is a non-mass dependent and dimensionless quantity. It is used to indicate the degree of diagenesis of straightchain geolipids, and is a numerical representation of how much of the original biological chainlength specificity is preserved in geological lipids
(Meyers and Ishiwatari, 1995). Since all samples examined are surface sediment, the difference in CPIs should reflect more different input sources than diagenetic change. As shown in Fig. 6, it is noted that three northernmost stations exhibit high CPIs, which are not seen in Fig. 5. Sample 456-37 (at the northwest corner of the study area), located on the Keelung shelf, has been investigated for grain size effect on CPI. The unfractionated sample has a CPI value of 3.19 , and the $<30$ mesh fraction has a CPI value of 5.30. This is not in accord with the general observation that CPIs decrease as particle-size decreases (Thompson and Eglinton, 1978; Meyers and Ishiwatari, 1995). It is thought that the larger particle size ( $>30$ mesh)

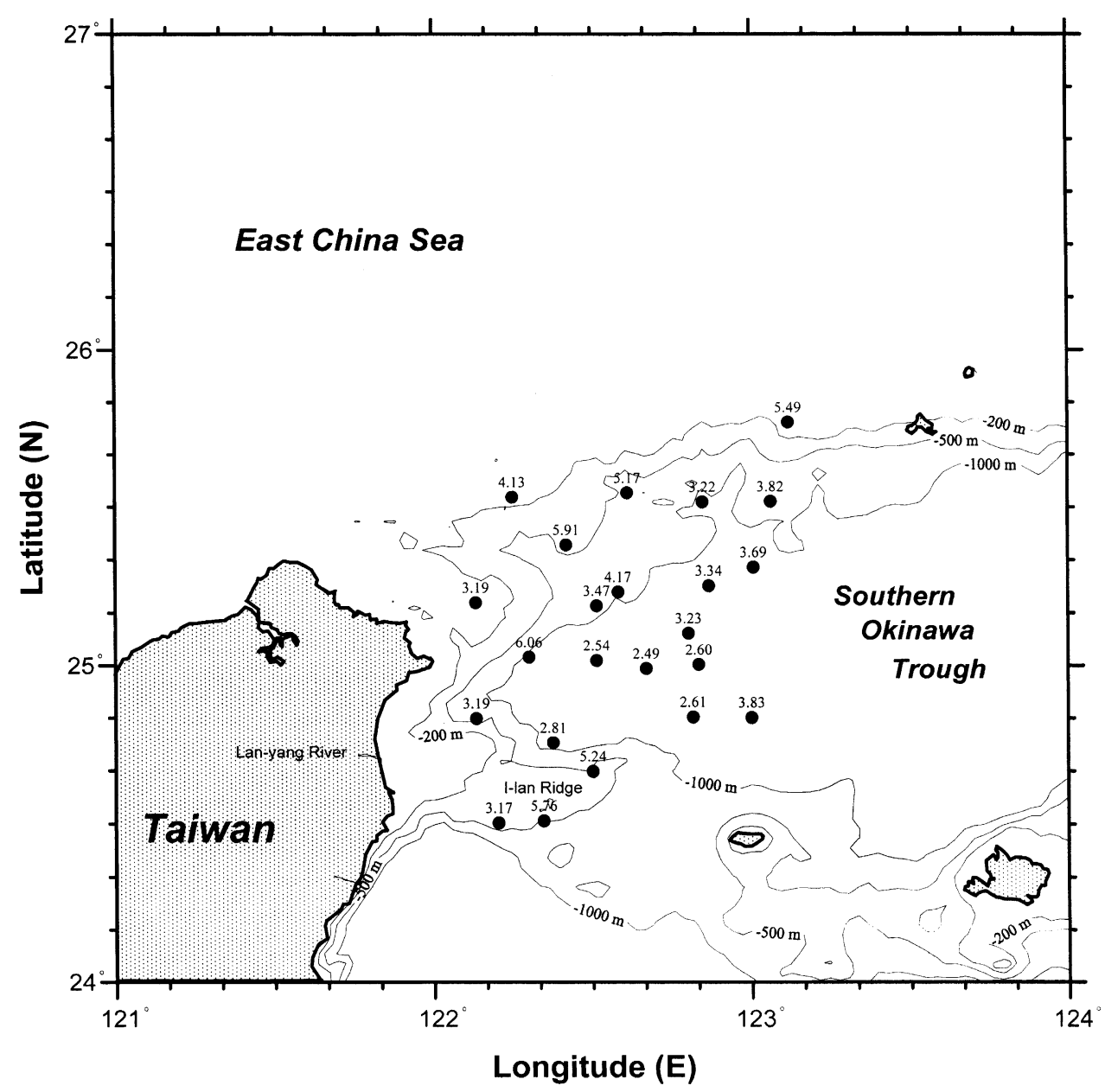

Fig. 6. Spatial distribution of carbon preference index $\left(\mathrm{CPI}_{25-33}\right)$ of $n$-alkanes. 
fraction is made up of eroded older (relict) sediment containing degraded lipids with low CPIs and that the smaller particle size $(<30$ mesh) fraction contains recent sediment with high CPIs. One important feature is that the three stations nearest to Taiwan exhibit low CPIs (3.19, 3.19 and 3.17) and that the highest CPIs are farther from shore. This does not seem to be reasonable if the sediment source is Taiwan.

Geographically, the Lan-yang River, which discharges its sediment (ca. $8.0 \mathrm{Mt} / \mathrm{yr}$, Water Resources Bureau, 1998) directly into the study area, plays a major role in the distribution of terrigenous lipids in the study area, and the CPI signature of its suspended sediments is expected to reflect that of marine sediments. Three samples of total suspended matter from the river have CPIs of 1.38 (Fig. 7), 1.43 and 1.46, which are lower than those of the marine sediments. The result is consistent with a recent report that modern carbon in the POC discharged from the main channel of the river was $<30 \%$ (Kao and Liu, 1996). In other words, the particulates in the river water are mainly old material, which tends to have lower CPIs. This leads us to consider that, on the twoend member assumption, the marine sediments examined are a mixture of two sources - high CPI sediment from either northwest or south of the study area and low CPI sediment from the nearby Lan-yang River. Those samples closest to Taiwan would have much higher CPIs if there were no input from the Lan-yang River. However, comparatively lower CPIs for the lower slope sediments can be attributed to contribution of old organic carbon from the Lan-yang River.

Terrestrial hydrocarbons (for example, the plant wax alkanes and retene) in Washington shelf sediments have been found to be highly concentrated in the sand-sized, low-density fraction (particles $<1.9 \mathrm{~g} / \mathrm{ml}$ ) of bulk sediments (Prahl and Carpenter, 1983). However, the sediments off northeastern Taiwan have somewhat high concentrations of plant wax alkanes, but have comparatively low sand contents except some stations located in the north. For instance, two samples taken from this area (lower slope) have sand contents of $2.2 \%$ and $2.5 \%$ (Jeng and Chen, 1995). Deploying ten moorings for sediment traps in the northern half of our study area, Chung and Hung (2000) found that the major components of the trap samples in the canyon were silt and sand, but those on the slope were mainly silt. This difference can be attributed to different depositional environments. The low sand percentage could be due to the effect of the Kuroshio Current which turns northeastward in the study area. Coarse suspended particles from the East China Sea shelf are blocked by the Kuroshio and not deposited on the immediate shelf off north Taiwan, and fine particles cross the shelf and settle on the slope of the southern Okinawa Trough (Chen et al., 1992).

The distribution of $n$-fatty alcohols shows a general distribution pattern maximizing at $\mathrm{C}_{22}$ (for the samples on the lower slope in particular, Fig. 8) or $>\mathrm{C}_{22}$. Cranwell (1981) suggests that decomposer organisms may be the source of the $n$ $\mathrm{C}_{22}$ alcohol present in the sediments; however, Jeng and Chen (1995), studying the grain size effect, show that bacteria do not seem to be the source of the $\mathrm{C}_{22}$ alcohol. Recent study indicates that the $\mathrm{C}_{22}$ alcohol can be contributed from freshwater and marine sources (Volkman et al., 1998; and references therein). Lan-yang River suspended matter has an $n$-alkanol distribution with a maximum at $\mathrm{C}_{22}$ (Fig. 7), which may play a role in the marine sediments. The low-molecularweight alkanols $\left(n-\mathrm{C}_{14}-n-\mathrm{C}_{22}\right)$, which may be formed by hydrolysis of esterified alcohols derived from a wide variety of organisms, such as zooplankton (Boon and de Leeuw, 1979), are considered to be from marine sources. The major alcohols of zooplankton are $\mathrm{C}_{16: 0}, \mathrm{C}_{20: 1}$, and $\mathrm{C}_{22: 1}$ (Kattner and Krause, 1989). Higher plants generally have their $n$-alkanol distribution $>\mathrm{C}_{22}$ (Kolattukudy, 1970; Wannigama et al., 1981). Linear regression between $n-\mathrm{C}_{22} \mathrm{OH}$ and other biomarker $n$-alkanols (Table 4) shows that the relationship is better correlated for $\mathrm{C}_{20}, \mathrm{C}_{24}, \mathrm{C}_{26}$, and $\mathrm{C}_{28}$ than for $\mathrm{C}_{14}, \mathrm{C}_{16}$, and $\mathrm{C}_{18} n$-alkanols. This result appears to indicate that the sediments have received more $n-\mathrm{C}_{22} \mathrm{OH}$ from terrigenous sources than from marine sources. In addition, Lan-yang River suspended matter also contains a high concentration of phytol (Fig. 7), which may contribute to the marine sediments. Linear regression of phytol against other biomarker $n$-alkanols 


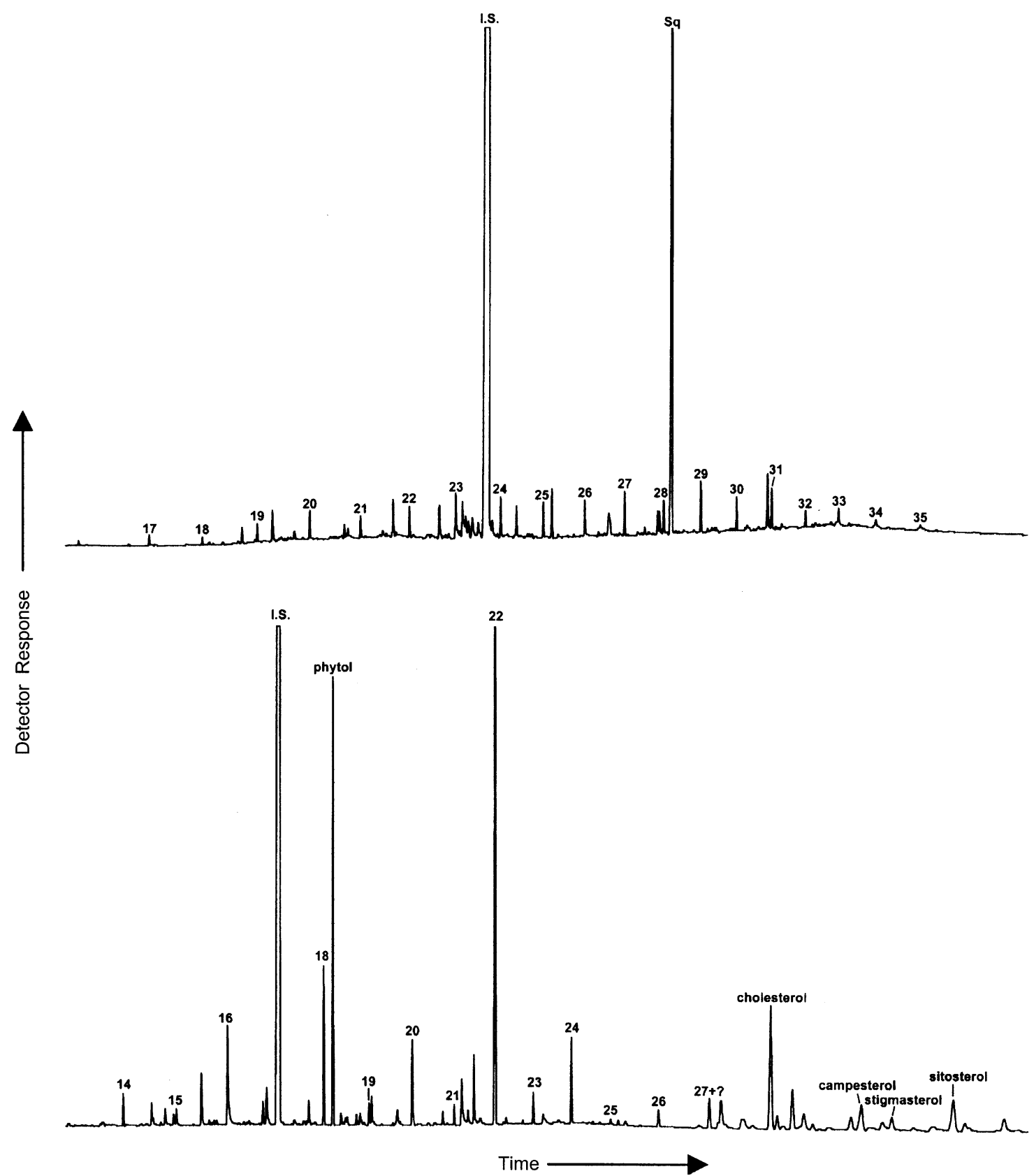

Fig. 7. (upper) Gas chromatogram of the aliphatic fraction from the Lan-yang River suspended matter. Numbers above peaks refer to carbon number of $n$-alkanes; $\mathrm{Sq}=$ squalene; I.S. = internal standard $\left(n-\mathrm{C}_{24} \mathrm{D}_{50}\right) . \mathrm{CPI}_{25-33}=1.38$. (lower) Gas chromatogram of the alkanol/sterol fraction from the Lan-yang River suspended matter. Numbers above peaks refer to carbon number of $n$-alkanols; I.S. $=$ internal standard $\left(n-\mathrm{C}_{17} \mathrm{OH}\right)$. 


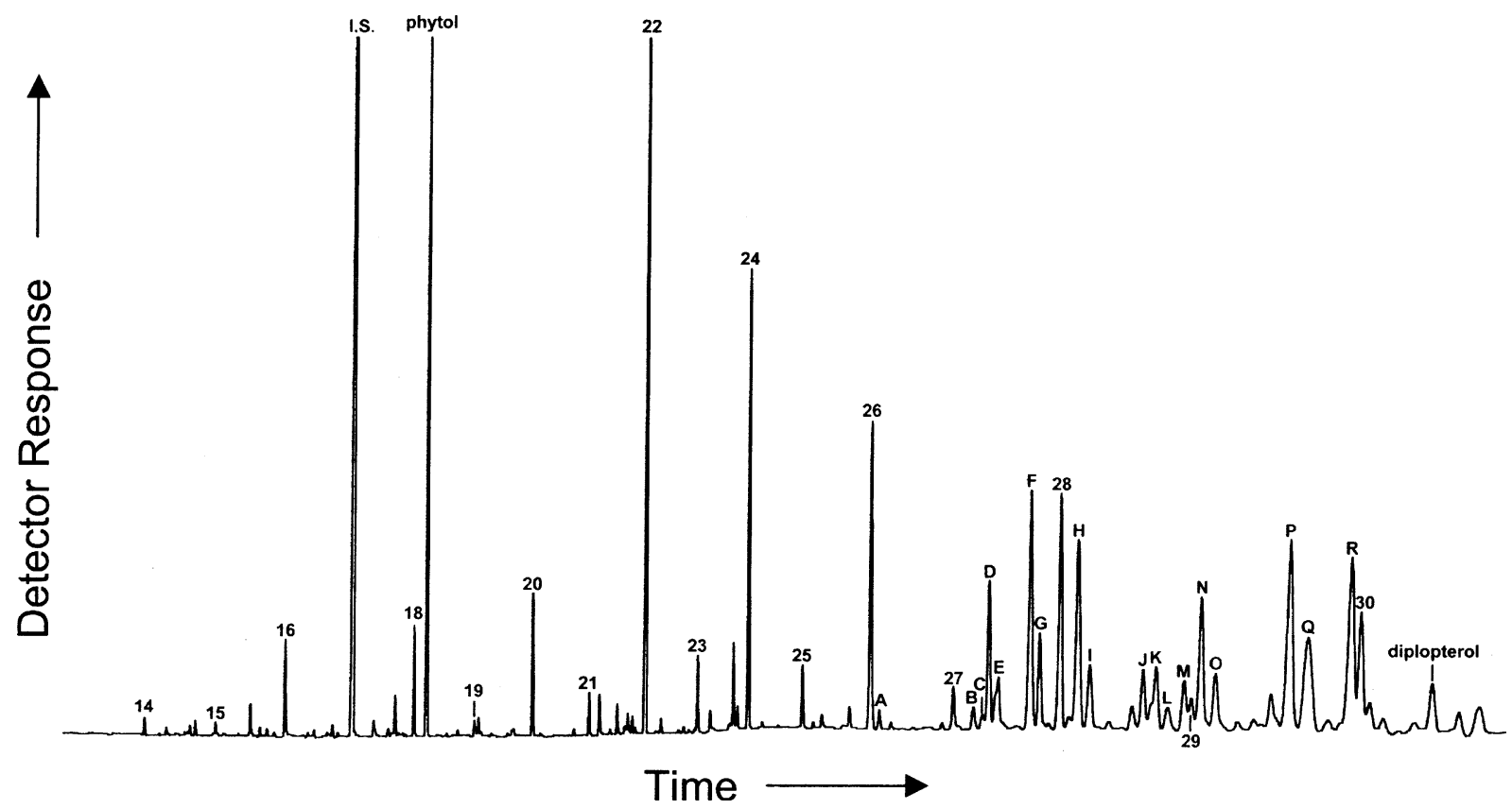

Fig. 8. Gas chromatogram of the alkanol/sterol fraction for sample 417-45. Numbers above peaks refer to carbon number of $n$ alkanols; I.S. $=$ internal standard $\left(n-\mathrm{C}_{17} \mathrm{OH}\right)$. Letters above peaks refer to sterols: (A) 24-nor-5 $\alpha$-cholest-22E-en-3 $\beta$-ol, (B) 27-nor-24methylcholesta-5,22E-dien-3 $\beta$-ol, (C) 27-nor-24-methyl-5 $\alpha$-cholest-22E-dien-3 $\beta$-ol, (D) cholesta-5,22E-dien-3 $\beta$-ol (22-dehydrocholesterol), (E) $5 \alpha$-cholest-22E-en-3 $\beta$-ol, (F) cholest-5-en-3 $\beta$-ol (cholesterol), (G) $5 \alpha$-cholestan-3 $\beta$-ol (cholestanol), (H) 24-methylcholesta5,22E-dien-3 $\beta$-ol (diatomsterol), (I) 24-methyl-5 $\alpha$-cholest-22E-en-3 $\beta$-ol, (J) 24-methylcholesta-5,24(28)-dien-3 $\beta$-ol (24-methylenecholesterol), (K) 24-methylcholest-5-en-3 $\beta$-ol (campesterol) + 24-methyl-5 $\alpha$-cholest-24(28)-en-3 $\beta$-ol(?), (L) 24-methyl-5 $\alpha$-cholestan-3 $\beta$-ol, (M) 23,24-dimethylcholesta-5,22E-dien-3 $\beta$-ol, (N) 24-ethylcholesta-5,22E-dien-3 $\beta$-ol (stigmasterol), (O) 24-ethyl-5 $\alpha$-cholest-22E-en-3 $\beta$ ol, (P) 24-ethylcholest-5-en-3 $\beta$-ol (sitosterol), (Q) 24-ethyl-5 $\alpha$-cholestan-3 $\beta$-ol + unknown, and (R) $4 \alpha, 23,24-$ trimethyl-5 $\alpha$-cholest-22Een-3 $\beta$-ol (dinosterol). Dipl. $=$ diplopterol.

(Table 5) shows that phytol is better correlated with $\mathrm{C}_{14}, \mathrm{C}_{16}, \mathrm{C}_{18}$, and $\mathrm{C}_{20}$ than with $\mathrm{C}_{24}, \mathrm{C}_{26}$, and $\mathrm{C}_{28} n$-alkanols, indicating that the sedimentary phytol receives more contribution from marine sources.

The ratio of $n-\mathrm{C}_{16} \mathrm{OH}$ to $n-\mathrm{C}_{28} \mathrm{OH}$ was used by Venkatesan et al. (1987) as an index to show marine vs. terrigenous input of $n$-alkanols to the sediments. The ratios of the sediments range from 0.03 to 0.24 (with a single outlier of 3.70 ) with a mean of $0.13 \pm 0.06$ (Table 3), indicating the predominance of higher plant $n$-alkanols in the area, which is in agreement with the $n$-alkane distribution. To show the spatial distribution of terrestrial $n$-alkanols in the area, the sum of $n$ $\mathrm{C}_{24} \mathrm{OH}+n-\mathrm{C}_{26} \mathrm{OH}+n-\mathrm{C}_{28} \mathrm{OH}$ normalized to TOC was calculated (Table 3) and shown in Fig. 9. The spatial distribution pattern of $n$-fatty alcohols matches well with that of $n$-alkanes with respect to the occurrence of high values (shown in solid squares).

Three phytosterols - campesterol, stigmasterol, and $\beta$-sitosterol - are generally found in epicuticular waxes of vascular plants (Scheuer, 1973; Weete, 1976). They are a major part of the sterol fraction in the sediments analyzed (Fig. 8) and account for, on average, $24.3 \%$ of the total sterols (Table 6). The spatial distribution of the phytosterol concentrations normalized to TOC (Fig. 10) is totally different from those of $n$-alkanes and $n$ alkanols. The four stations with the highest values for $n$-alkanes and $n$-alkanols do not exhibit the highest values for phytosterols. Instead, the highest value spot is located just off northeastern Taiwan. It is seen from Fig. 10 that phytosterols are randomly distributed. The cause of this 
Table 3

Fatty alcohol data

\begin{tabular}{|c|c|c|c|c|c|c|c|c|}
\hline Sample & $\begin{array}{l}\text { TOC } \\
\left(10^{-2} \mathrm{~g} / \mathrm{g}\right)\end{array}$ & $\begin{array}{l}\text { Phytol } \\
\text { (ng/g) }\end{array}$ & $\begin{array}{l}n-\mathrm{C}_{16} \mathrm{OH} \\
(\mathrm{ng} / \mathrm{g})\end{array}$ & $\begin{array}{l}n-\mathrm{C}_{22} \mathrm{OH} \\
(\mathrm{ng} / \mathrm{g})\end{array}$ & $\begin{array}{l}n-\mathrm{C}_{28} \mathrm{OH} \\
(\mathrm{ng} / \mathrm{g})\end{array}$ & $\begin{array}{l}n-\mathrm{C}_{16} \mathrm{OH} / \\
n-\mathrm{C}_{28} \mathrm{OH}\end{array}$ & $\begin{array}{l}\sum n-\mathrm{C}_{24,26,28} \\
(\mathrm{ng} / \mathrm{g})\end{array}$ & $\begin{array}{l}\left(\sum n-C_{24,26,28} /\right. \\
\text { TOC }) \times 10^{-7}\end{array}$ \\
\hline \multicolumn{9}{|l|}{$O R I-417$} \\
\hline $5(0-5 \mathrm{~cm})$ & 1.01 & 981 & 96 & 695 & 682 & 0.14 & 1770 & 1750 \\
\hline $8(0-3 \mathrm{~cm})$ & 1.05 & 1740 & 215 & 880 & 881 & 0.24 & 2220 & 2120 \\
\hline $9(0-3 \mathrm{~cm})$ & 1.09 & 1100 & 139 & 489 & 632 & 0.22 & 1650 & 1520 \\
\hline $10(0-3 \mathrm{~cm})$ & 1.00 & 1110 & 148 & 863 & 701 & 0.21 & 1810 & 1810 \\
\hline $16(0-5 \mathrm{~cm})$ & 0.82 & 370 & 88 & 437 & 529 & 0.17 & 1420 & 1740 \\
\hline $20(0-4 \mathrm{~cm})$ & 0.63 & 350 & 72 & 903 & 1560 & 0.05 & 3940 & 6250 \\
\hline $21(0-4 \mathrm{~cm})$ & 0.77 & 1370 & 94 & 842 & 595 & 0.16 & 1590 & 2060 \\
\hline 27 & 0.16 & 66 & 15 & 194 & 154 & 0.10 & 350 & 2190 \\
\hline $34(0-4 \mathrm{~cm})$ & 0.69 & 204 & 59 & 857 & 1800 & 0.03 & 4380 & 6340 \\
\hline $36(0-4 \mathrm{~cm})$ & 0.42 & 65 & 46 & 758 & 1040 & 0.04 & 2740 & 6510 \\
\hline $37(0-4 \mathrm{~cm})$ & 0.29 & 34 & 30 & 374 & 162 & 0.19 & 378 & 1300 \\
\hline $42(0-4 \mathrm{~cm})$ & 0.41 & 138 & 34 & 480 & 259 & 0.13 & 652 & 1590 \\
\hline $43(0-4 \mathrm{~cm})$ & 0.73 & 431 & 53 & 694 & 418 & 0.13 & 1120 & 1530 \\
\hline $44(0-4 \mathrm{~cm})$ & 0.84 & 941 & 81 & 894 & 618 & 0.13 & 1630 & 1940 \\
\hline 45 & 0.87 & 863 & 72 & 750 & 553 & 0.13 & 1460 & 1680 \\
\hline $46(0-4 \mathrm{~cm})$ & 0.79 & 450 & 76 & 750 & 562 & 0.14 & 1460 & 1850 \\
\hline \multicolumn{9}{|l|}{$O R I-456$} \\
\hline 27 & 0.74 & 861 & 62 & 739 & 1120 & 0.06 & 2930 & 3960 \\
\hline $33(0-4 \mathrm{~cm})$ & 0.38 & 250 & 38 & 461 & 279 & 0.14 & 771 & 2030 \\
\hline $34(0-4 \mathrm{~cm})$ & 0.74 & 291 & 51 & 740 & 1540 & 0.03 & 4140 & 5590 \\
\hline 35 & 0.14 & 47 & 17 & 180 & 91 & 0.19 & 235 & 1680 \\
\hline 37 & 0.36 & 36 & 185 & 89 & 50 & 3.70 & 148 & 411 \\
\hline $39(0-4 \mathrm{~cm})$ & 0.71 & 888 & 77 & 433 & 673 & 0.11 & 1510 & 2130 \\
\hline $\mathrm{K}(0-4 \mathrm{~cm})$ & 0.60 & 451 & 40 & 599 & 367 & 0.11 & 966 & 1610 \\
\hline Average & & & & & & 0.13 & & \\
\hline 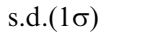 & & & & & & $0.06^{\mathrm{a}}$ & & \\
\hline
\end{tabular}

${ }^{\mathrm{a}}$ Exclusive of $456-37$.

Table 4

Linear regressions between $n-\mathrm{C}_{22} \mathrm{OH}$ and other biomarker $n$ alkanols for the 23 marine sediments

\begin{tabular}{llr}
\hline Regression & $r$ & $p$ \\
\hline$n-\mathrm{C}_{22} \mathrm{OH}=4.77 n-\mathrm{C}_{14} \mathrm{OH}+517$ & 0.24 & 0.26 \\
$n-\mathrm{C}_{22} \mathrm{OH}=0.890 n-\mathrm{C}_{16} \mathrm{OH}+544$ & 0.18 & 0.40 \\
$n-\mathrm{C}_{22} \mathrm{OH}=4.65 n-\mathrm{C}_{18} \mathrm{OH}+263$ & 0.58 & 0.004 \\
$n-\mathrm{C}_{22} \mathrm{OH}=4.45 n-\mathrm{C}_{20} \mathrm{OH}+131$ & 0.84 & $<0.001$ \\
$n-\mathrm{C}_{22} \mathrm{OH}=0.561 n-\mathrm{C}_{24} \mathrm{OH}+344$ & 0.74 & $<0.001$ \\
$n-\mathrm{C}_{22} \mathrm{OH}=0.411 n-\mathrm{C}_{26} \mathrm{OH}+382$ & 0.69 & $<0.001$ \\
$n-\mathrm{C}_{22} \mathrm{OH}=0.360 n-\mathrm{C}_{28} \mathrm{OH}+374$ & 0.70 & $<0.001$ \\
\hline
\end{tabular}

$r=$ correlation coefficient, $p=$ significance value.
Table 5

Linear regressions of phytol against other biomarker $n$-alkanols for the 23 marine sediments

\begin{tabular}{llr}
\hline Regression & $r$ & $P$ \\
\hline Phytol $=24.6 n-\mathrm{C}_{14} \mathrm{OH}+74.1$ & 0.63 & 0.001 \\
Phytol $=6.05 n-\mathrm{C}_{16} \mathrm{OH}+97.2$ & 0.64 & 0.001 \\
Phytol $=11.6 n-\mathrm{C}_{18} \mathrm{OH}-311$ & 0.73 & $<0.001$ \\
Phytol $=7.60 n-\mathrm{C}_{20} \mathrm{OH}-256$ & 0.73 & $<0.001$ \\
Phytol $=1.07 n-\mathrm{C}_{22} \mathrm{OH}-90.2$ & 0.54 & 0.007 \\
Phytol $=0.266 n-\mathrm{C}_{24} \mathrm{OH}+440$ & 0.18 & 0.42 \\
Phytol $=0.180 n-\mathrm{C}_{26} \mathrm{OH}+466$ & 0.15 & 0.48 \\
Phytol $=0.162 n-\mathrm{C}_{28} \mathrm{OH}+460$ & 0.16 & 0.47 \\
\hline
\end{tabular}

$r=$ correlation coefficient, $p=$ significance value. 


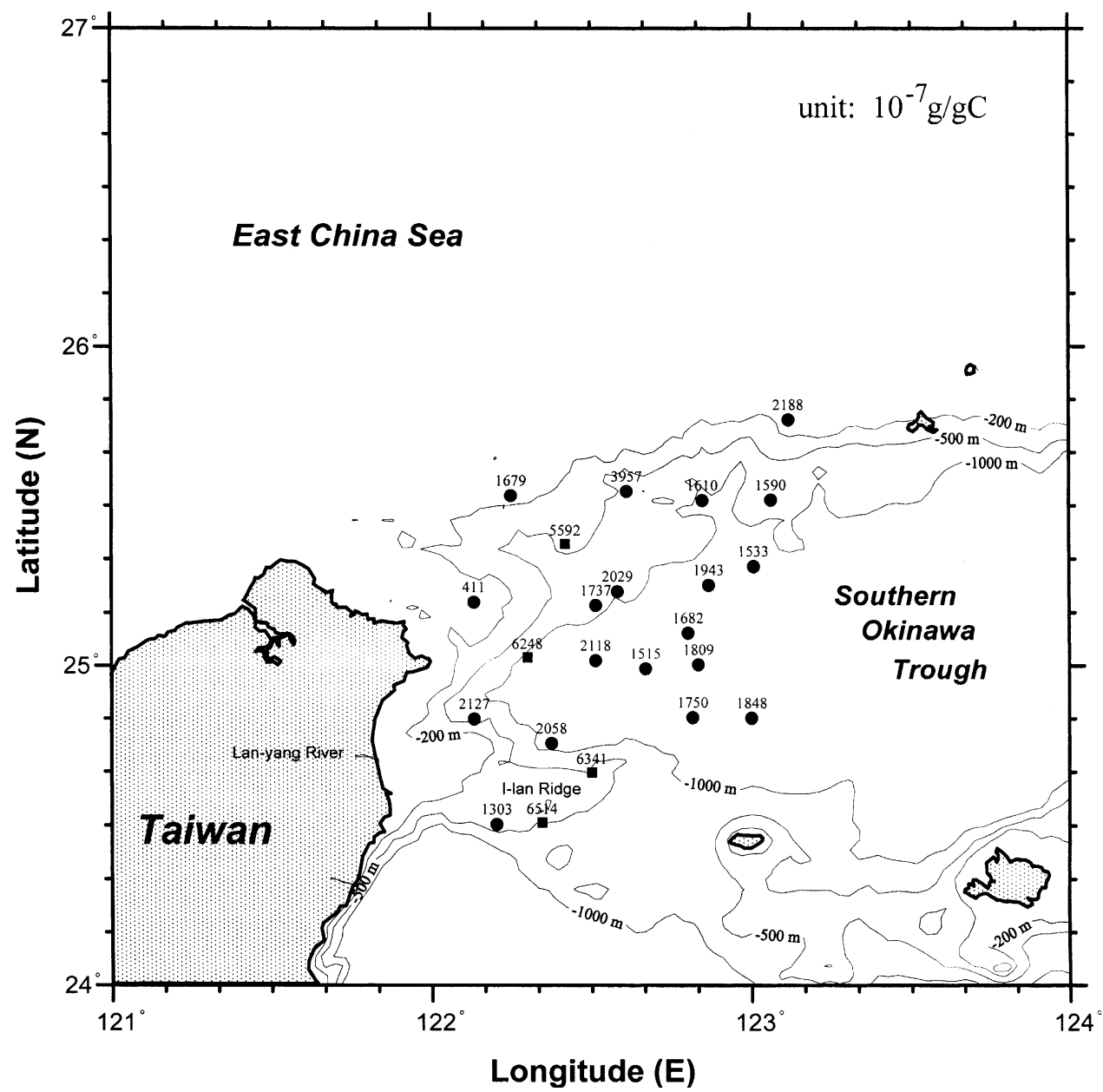

Fig. 9. Spatial distribution of plant wax $n$-fatty alcohols $\left(n-\mathrm{C}_{24} \mathrm{OH}+n-\mathrm{C}_{26} \mathrm{OH}+n-\mathrm{C}_{28} \mathrm{OH}\right)$ normalized to TOC.

difference is unclear. Part of the reason might be that the three phytosterols originally thought to be terrigenous markers also could be produced by marine organisms (Volkman, 1986).

\subsection{Correlation between TOC and terrigenous lipid biomarkers}

Linear regression of TOC versus concentrations of land plant wax $n$-alkanes (sum of $n-\mathrm{C}_{25}, n-\mathrm{C}_{27}$, $n-\mathrm{C}_{29}, n-\mathrm{C}_{31}$ and $n-\mathrm{C}_{33}$ ) in sediments is expected to give a strong positive linear correlation if a point source exists in a region of interest, such as that for the Columbia River drainage basin (Hedges and Prahl, 1993). The relationship for the sediments in the study area is positive but weak $(r=0.64$, $p=0.001)$. Linear regression of TOC against concentrations of land plant wax $n$-alkanols (sum of $n-\mathrm{C}_{24} \mathrm{OH}, n-\mathrm{C}_{26} \mathrm{OH}$ and $\left.n-\mathrm{C}_{28} \mathrm{OH}\right)$ also shows positive linear correlation $(r=0.42, p=0.048)$, which is weaker. This result could be attributed to several factors: (1) a complex input (not a point source) of terrigenous organic matter to the study area, (2) sediment receiving a blend of eroded and recent lipids (discussed earlier), (3) TOC also including marine organic matter, (4) temporal variations in river flow due to flooding, and (5) different rates of degradation for TOC and individual biomarkers. However, there is a strong positive linear relationship between TOC and the 
Table 6

Sterol and diplopterol data

\begin{tabular}{|c|c|c|c|c|c|c|c|c|}
\hline Sample & $\begin{array}{l}\text { TOC } \\
(\mathrm{g} / 100 \mathrm{~g})\end{array}$ & $\begin{array}{l}\text { Campesterol } \\
(\mathrm{ng} / \mathrm{g})\end{array}$ & $\begin{array}{l}\text { Stigmasterol } \\
(\mathrm{ng} / \mathrm{g})\end{array}$ & $\begin{array}{l}\text { Sitosterol } \\
(\mathrm{ng} / \mathrm{g})\end{array}$ & $\begin{array}{l}\text { Total }^{\mathrm{a}} \\
\text { Phytosterols } \\
\text { (ng/g) }\end{array}$ & $\begin{array}{l}\text { (Total } \\
\text { phytosterols/ } \\
\text { TOC) } \times 10^{-7}\end{array}$ & $\begin{array}{l}\text { Total sterols } \\
(\mathrm{ng} / \mathrm{g})\end{array}$ & $\begin{array}{l}\text { Diplopterol } \\
\text { (ng/g) }\end{array}$ \\
\hline \multicolumn{9}{|l|}{$O R I-417$} \\
\hline $5(0-5 \mathrm{~cm})$ & 1.01 & 257 & 432 & 1000 & 1690 & 1670 & 6270 & 3050 \\
\hline $8(0-3 \mathrm{~cm})$ & 1.05 & 416 & 630 & 1260 & 2360 & 2200 & 9340 & 2960 \\
\hline $9(0-3 \mathrm{~cm})$ & 1.09 & 398 & 587 & 1080 & 2060 & 1890 & 7870 & 401 \\
\hline $10(0-3 \mathrm{~cm})$ & 1.00 & 287 & 479 & 1010 & 1780 & 1780 & 6640 & 892 \\
\hline $16(0-5 \mathrm{~cm})$ & 0.82 & 313 & 455 & 772 & 1540 & 1880 & 6190 & 79 \\
\hline $20(0-4 \mathrm{~cm})$ & 0.63 & 116 & 79 & 282 & 477 & 757 & 2200 & 55 \\
\hline $21(0-4 \mathrm{~cm})$ & 0.77 & 214 & 377 & 727 & 1320 & 1710 & 5540 & 492 \\
\hline 27 & 0.16 & 25 & 13 & 32 & 70 & 438 & 449 & 26 \\
\hline $34(0-4 \mathrm{~cm})$ & 0.69 & 112 & 101 & 362 & 575 & 833 & 2450 & 85 \\
\hline $36(0-4 \mathrm{~cm})$ & 0.42 & 84 & 117 & 332 & 533 & 1270 & 2130 & 51 \\
\hline $37(0-4 \mathrm{~cm})$ & 0.29 & 36 & 33 & 92 & 161 & 555 & 869 & 13 \\
\hline $42(0-4 \mathrm{~cm})$ & 0.41 & 62 & 118 & 246 & 426 & 1040 & 1520 & 38 \\
\hline $43(0-4 \mathrm{~cm})$ & 0.73 & 94 & 190 & 390 & 674 & 923 & 2780 & 130 \\
\hline $44(0-4 \mathrm{~cm})$ & 0.84 & 191 & 346 & 669 & 1210 & 1440 & 4960 & 232 \\
\hline 45 & 0.87 & 213 & 344 & 685 & 1240 & 1430 & 4860 & 376 \\
\hline $46(0-4 \mathrm{~cm})$ & 0.79 & 117 & 197 & 502 & 816 & 1030 & 3320 & 786 \\
\hline \multicolumn{9}{|l|}{$O R I-456$} \\
\hline 27 & 0.74 & 220 & 191 & 544 & 955 & 1290 & 4550 & 90 \\
\hline $33(0-4 \mathrm{~cm})$ & 0.38 & 86 & 111 & 403 & 501 & 1320 & 1810 & 71 \\
\hline $34(0-4 \mathrm{~cm})$ & 0.74 & 178 & 178 & 434 & 790 & 1070 & 3220 & 108 \\
\hline 35 & 0.14 & 15 & 22 & 44 & 81 & 579 & 371 & 12 \\
\hline 37 & 0.36 & 107 & 162 & 392 & 661 & 1840 & 2610 & 38 \\
\hline $39(0-4 \mathrm{~cm})$ & 0.71 & 495 & 502 & 1100 & 2090 & 2950 & 8180 & 187 \\
\hline $\mathrm{K}(0-4 \mathrm{~cm})$ & 0.60 & 113 & 174 & 399 & 686 & 1140 & 2660 & 128 \\
\hline
\end{tabular}

${ }^{\text {a }}$ Phytosterols $=$ campesterol + stigmasterol + sitosterol.

concentration of phytosterols (sum of campesterol, stigmasterol and sitosterol), $r=0.85(p<0.001)$. The strong positive correlation could mean that the mixing or dilution of phytosterols in terrestrial organic carbon with marine organic carbon with or without the phytosterols follows a nearly constant ratio, which is especially remarkable for the study area with a complex input.

\subsection{Source of diploptene}

Both diploptene (hop-22(29)-ene, Fig. 1) and diplopterol (hopan-22-ol, Fig. 8) were found in the sediments; their EI mass spectra are given in Fig. 11. Diploptene is derived from terrestrial higher plants and is also formed by bacteria. If it is derived from higher plants, a strong correlation between diploptene and terrestrial higher plant $n$ alkanes has been demonstrated (Prahl et al., 1992). A plot of diploptene versus $\Sigma \mathrm{C}_{25-33} n$-alkanes (odd carbon only) for our samples shows scatter (Fig. 12), indicating no correlation. The diploptene in the study area is not predominantly derived from terrestrial higher plants, but from bacteria. It is also known that diplopterol is present in many bacteria and that concentrations up to $1600 \mu \mathrm{g} / \mathrm{g}$ dry wt have been found in some methylotrophs, although small amounts of diplopterol also have been found in some cyanobacteria, mosses and ferns (Rohmer et al., 1984). Moreover, diplopterol plotted against diploptene exhibits strong positive linear correlation $(r=0.93, p<0.001$, Fig. 12). This result suggests that the diploptene in the study area may be mainly derived from diplopterol 


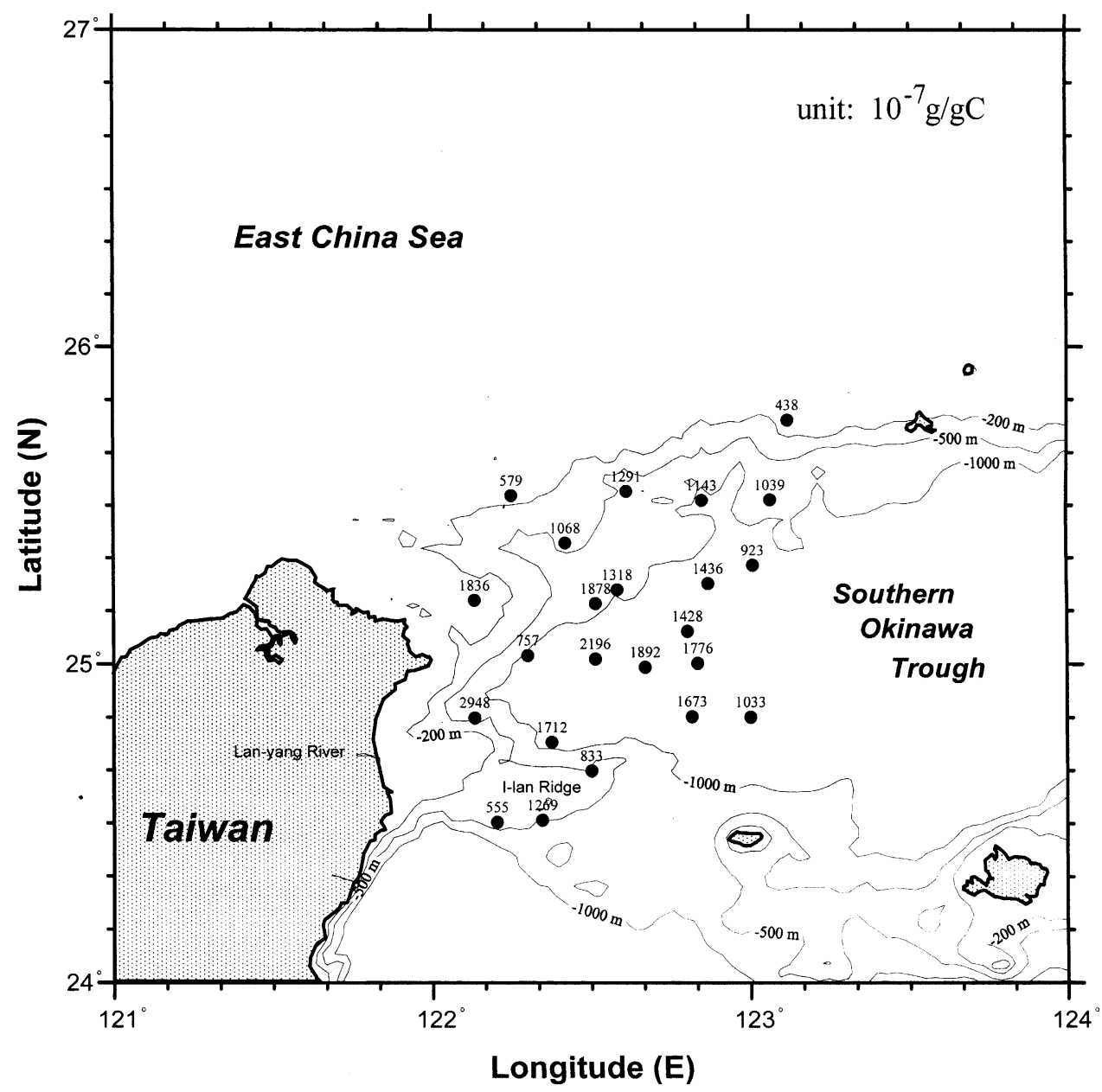

Fig. 10. Spatial distribution of phytosterols normalized to TOC.

through dehydration in early diagenesis. In addition, many active submarine hydrothermal activities in the study area have been observed in the southern Okinawa Trough (Lee et al., 1998). Furthermore, an extraordinarily high concentration $(23730 \mathrm{nl} / 1)$ of dissolved methane in the bottom water (depth $1440 \mathrm{~m}$ ) was found at $25^{\circ} 04.18^{\prime} \mathrm{N}, \quad 122^{\circ} 35.20^{\prime} \mathrm{E}$ (KEEP-MASS, 1992) although other high levels of dissolved methane in the bottom waters were also found in the study area (Chen, 1994). Subsequent collection of bottom water (within $2 \mathrm{~m}$ of sea bottom) and sediment simultaneously using a specially-designed sampler for methane study was made closest to this site. Abnormally high to high dissolved methane concentrations in bottom water were observed at stations $\mathrm{P}\left(25^{\circ} 03.12^{\prime} \mathrm{N}, 122^{\circ} 34.23^{\prime} \mathrm{E}\right.$; water depth $1283 \mathrm{~m}), \mathrm{Q}\left(25^{\circ} 04.37^{\prime} \mathrm{N}, 122^{\circ} 35.32^{\prime} \mathrm{E}\right.$; water depth $1395 \mathrm{~m})$ and $\mathrm{R}\left(25^{\circ} 04.88^{\prime} \mathrm{N}\right.$, $122^{\circ} 40.07^{\prime} \mathrm{E}$; water depth $\left.1380 \mathrm{~m}\right)-11100,1500$ and $320 \mathrm{nl} / 1$, respectively (Chen, 1994). As shown in Fig. 13, relatively high diploptene and diplopterol concentrations in sediments also were obtained at stations Q (5440 and $7550 \mathrm{ng} / \mathrm{g}$, respectively) and $\mathrm{R}$ (1380 and $842 \mathrm{ng} / \mathrm{g}$, respectively). If stations $\mathrm{Q}$ and $\mathrm{R}$ are included in Fig. 12, the regression equation is diplopterol $=-38.7+1.40$ diploptene $(r=0.97, p<0.001)$. This leads us to consider some relation between methane, diplopterol and diploptene. As a 

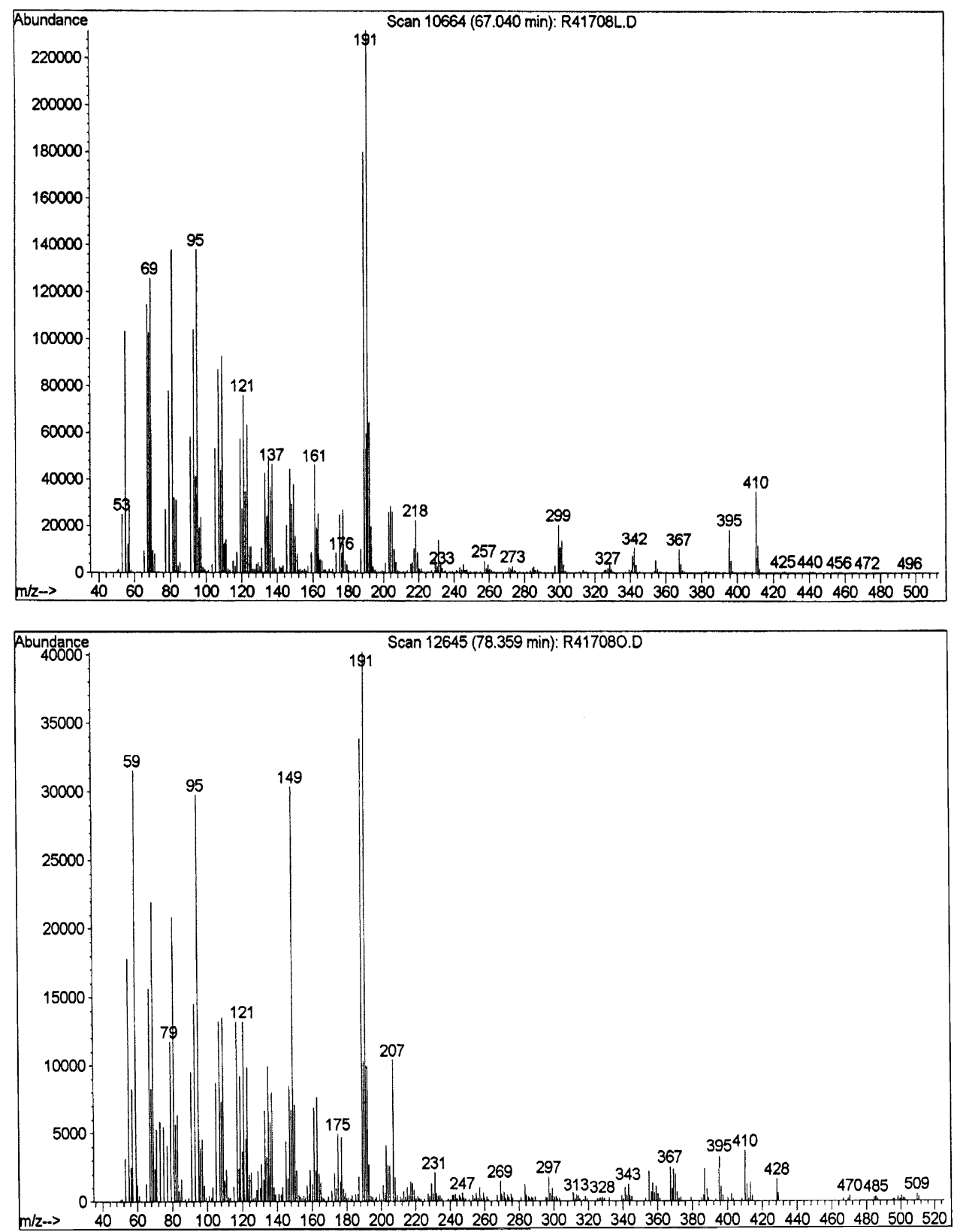

Fig. 11. Electron impact mass spectra of diploptene (upper) and diplopterol (lower) from station 417-8. Note that the present silylation procedure using BSA alone did not silylate diplopterol, and the spectrum shown here represents its free form.

consequence, it is speculated that diplopterol in the sediments could be synthesized by methylotrophic bacteria using methane as their carbon source.

\section{Conclusions}

Compared with other coastal areas, the sediments off northeastern Taiwan contain comparatively 

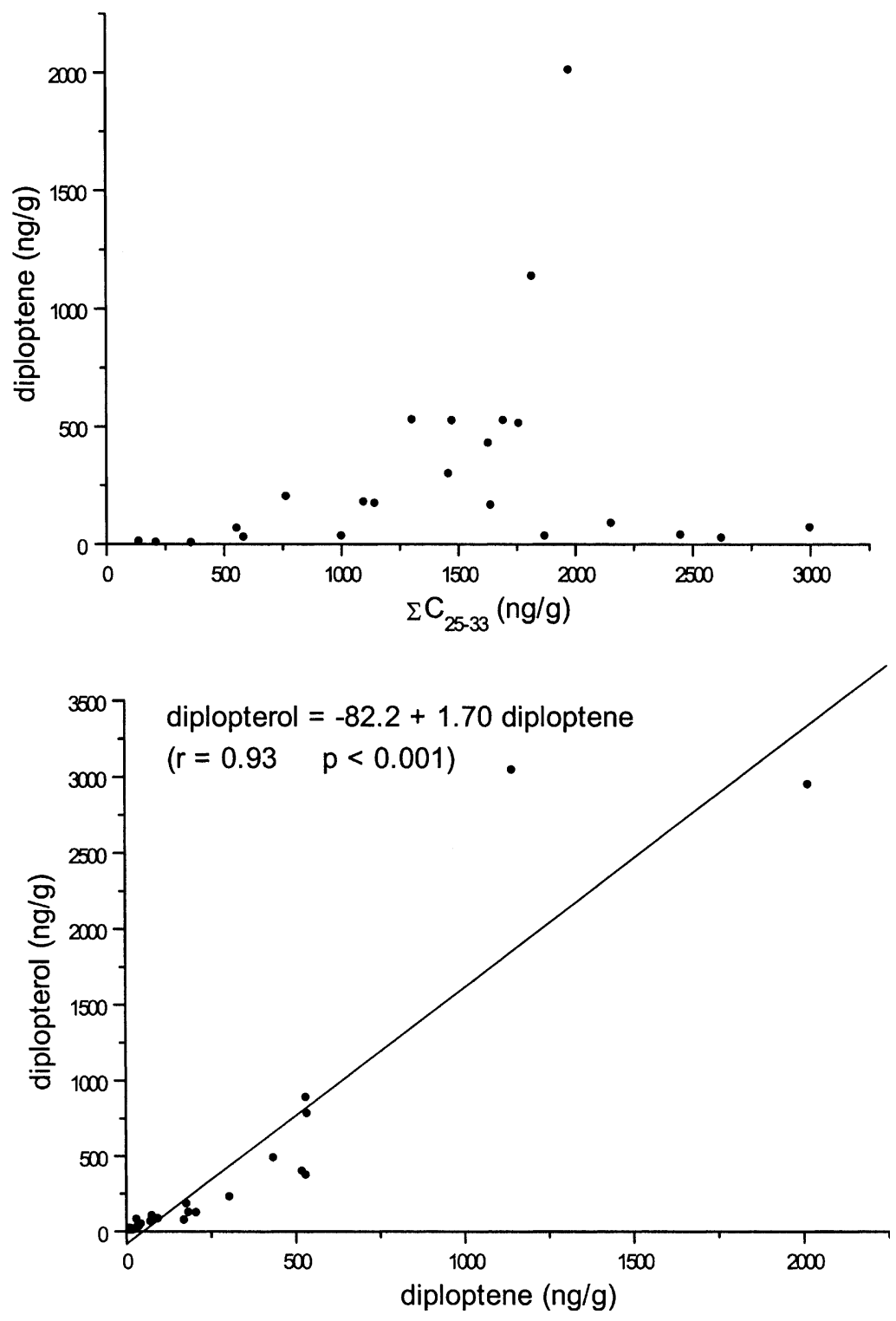

Fig. 12. (upper) Plot of diploptene versus $\mathrm{CPI}_{25-33}$ of $n$-alkanes and (lower) plot of diplopterol versus diploptene.

high proportions of terrigenous $n$-alkanes and $n$-alkanols. The highest concentrations of plant waxes were found on the upper slope of the southernmost Okinawa Trough near Taiwan. The major terrigenous inputs to this area are particle fluxes from the southern East China Sea shelf and river runoff from the east Taiwan coast. However, contribution from the Lan-yang River input is less important. TOC and phytosterol concentrations are positively correlated $(r=0.85$, $p<0.001)$.

In general, the present results show that the $n$-alkane and $n$-alkanol concentrations from marine sources are smaller than those from terrigenous sources. Therefore, biased conclusions may be obtained if only $n$-alkanes and $n$-alkanols are 


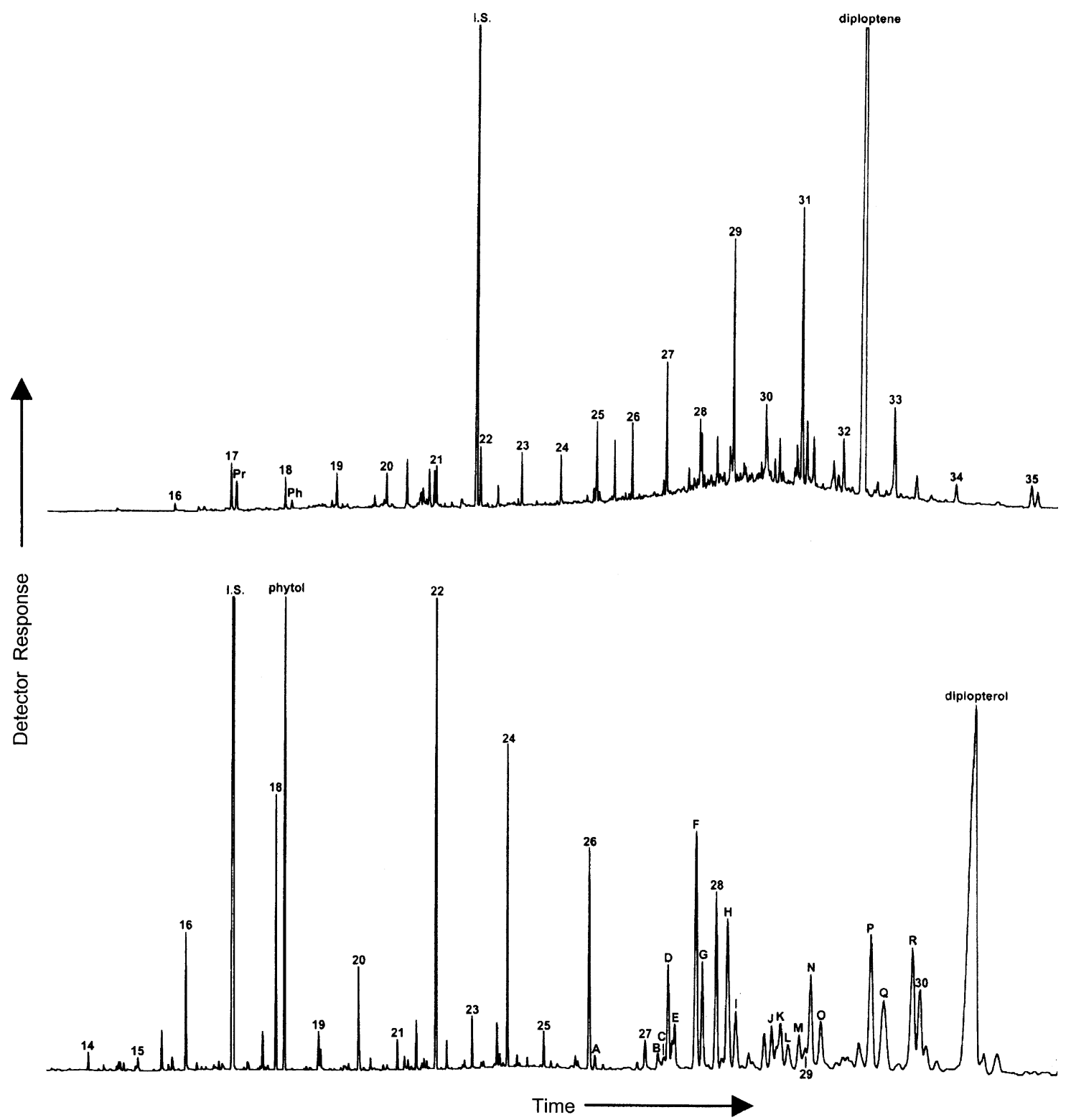

Fig. 13. Chromatograms containing diploptene (upper) and diplopterol (lower) from station Q with high concentration of dissolved methane in overlying bottom water. Note that the retention time of diploptene differs from that of Fig. 1 since the analysis was made earlier using an SE-30 column. Numbers above peaks refer to carbon number of $n$-alkanes (upper) and $n$-alkanols (upper). Letters above peaks refer to sterols; their identifications as in Fig. 8.

considered. In effect, our data do indicate that some marine-derived lipids outweigh terrigenous ones such as phytol and sterols. The observed lower concentrations of marine lipids in the sediments are attributed to the fact that terrige- nous lipids are often preferentially preserved due to sequestration and that marine lipids are more prone to degradation in the marine environment especially those compounds derived from plankton. 


\section{Acknowledgements}

We thank the captain, crew and technicians of the R/V Ocean Researcher I for help with sediment collection. Our special thanks go to Dr. M. C. Kennicutt, II and Dr. J. K. Volkman for constructive comments and suggestions. This study was financially supported by the National Science Council, Republic of China (grant no. NSC85-2611-M002A-020-K2).

\section{References}

Bigot, M., Saliot, A., Qiu, Y.J., Yang, Z., Tang, Y., 1990. Hydrocarbons in surficial sediments from the Changjiang estuary and adjacent East China Sea. In: Yu, G., et al. (Ed.), Biogeochemical Study of the Changjiang Estuary. China Ocean Press, China, pp. 667-675.

Blumer, M., Guillard, R.R.L., Chase, T., 1971. Hydrocarbons of marine phytoplankton. Marine Biology 8, 183-189.

Boon, J.J., de Leeuw, J.W., 1979. The analysis of wax esters, very long mid-chain ketones and sterol ethers isolated from Walvis Bay diatomaceous ooze. Marine Chemistry 7 , $117-132$.

Brassell, S.C., Eglinton, G., 1980. Environmental chemistry An interdisciplinary subject. Natural and pollutant organic compounds in contemporary aquatic environments. In: Albaiges, J. (Ed.), Analytical Techniques in Environmental Chemistry. Pergamon Press, Oxford, pp. 1-22.

Burns, K.A., Teal, J.M., 1973. Hydrocarbons in the pelagic Sargassum community. Deep-Sea Research 20, 207-211.

Chen, M.P., Lo, S.C., Lin, K.L., 1992. Composition and texture of surface sediment indicating the depositional environments off northeast Taiwan. Terrestrial, Atmospheric, and Oceanic Sciences (ROC) 3, 395-418.

Chen, M.P., Lin, K.L., Huang, C.K., 1995. Sedimentary structure and texture of surficial sediment off northeastern Taiwan. Ti-Chih (ROC) 15, 15-47 (in Chinese with English abstract).

Chen, Y.K., 1994. Dissolved methane off north Taiwan. M.S. Thesis, National Taiwan University.

Chern, C.S., Wang, J., Wang, D.P., 1990. The exchange of Kuroshio and the East China Sea shelf water. Journal of Geophysical Research 95, 16017-16023.

Chung, Y., Chang, W.C., 1995. Pb-210 fluxes and sedimentation rates on the lower continental slope between Taiwan and the South Okinawa Trough. Continental Shelf Research 15, 149-164.

Chung, Y., Hung, G.W., 2000. Particulate fluxes and transports on the slope between the southern East China Sea and the South Okinawa Trough. Continental Shelf Research 20, 571-597.
Cranwell, P.A., 1981. Diagenesis of free and bound lipids in terrestrial detritus deposited in a lacustrine sediment. Organic Geochemistry 3, 79-89.

Cranwell, P.A., 1984. Lipid geochemistry of sediments from Upton Broad, a small productive lake. Organic Geochemistry $7,25-37$.

Cripps, G.C., 1995. Biogenic hydrocarbons in the particulate material of the water column of the Bellingshausen Sea, Antarctica, in the region of the marginal ice zone. Deep-Sea Research II 42, 1123-1135.

Currie, B.R., Johns, R.B., 1989. An organic geochemical analysis of terrestrial biomarkers in a transect of the Great Barrier Reef lagoon. Australian Journal of Marine and Freshwater Research 40, 275-284.

Eglinton, G., Hamilton, R.J., 1963. The distribution of alkanes. In: Swain, T. (Ed.), Chemical Plant Taxonomy. Academic Press, New York, pp. 187-217.

Eglinton, G., Hamilton, R.J., 1967. Leaf epicuticular waxes. Science 156, 1322-1335.

Elias, V.O., Cardoso, J.N., 1996. Sources and transport of lipids on Amazon continental shelf. Geo-Marine Letters 16, 11-16.

Farrington, J.W., Tripp, B.W., 1977. Hydrocarbons in western North Atlantic surface sediments. Geochimica et Cosmochimica Acta 41, 1627-1641.

Gagosian, R.B., Volkman, J.K., Nigrelli, G.E., 1983. The use of sediment traps to determine sterol sources in coastal sediments off Peru. In: Bjorøy, M., et al. (Ed.), Advances in Organic Geochemistry 1981. Wiley, Chichester, pp. 369-379.

Gearing, P., Gearing, J.N., Lytle, T.F., Lytle, J.S., 1976. Hydrocarbons in 60 northeast Gulf of Mexico shelf sediments: a preliminary survey. Geochimica et Cosmochimca Acta 40, 1005-1017.

Hedges, J.I., Prahl, F.G., 1993. Early diagenesis: consequences for applications of molecular biomarkers. In: Engel, M.H., Macko, S.A. (Eds.), Organic Geochemistry: Principles and Applications. Plenum Press, New York, pp. 237-253.

Hsu, S.C., Lin, F.J., Jeng, W.L., Tang, T.Y., 1998. The effect of a cyclonic eddy on the distribution of lithogenic particles in the southern East China Sea. Journal of Marine Research 56, 813-832.

Huang, W.Y., Meinschein, W.G., 1976. Sterols as source indicators of organic materials in sediments. Geochimica et Cosmochimica Acta 40, 323-330.

Hung, G.W., Chung, Y., 1994. Sedimentation rates on the continental slope off eastern Taiwan. Marine Geology 119, 99-109.

Hung, G.W., Chung, Y., 1998. Particulate fluxes, ${ }^{210} \mathrm{~Pb}$ and ${ }^{210}$ Po measured from sediment trap samples in a canyon off northeastern Taiwan. Continental Shelf Research 18, 1475-1491.

Jeng, W.L., 1978. Hydrocarbons in the surface sediments of northern Taiwan Strait. Acta Oceanographica Taiwanica 8, $80-86$.

Jeng, W.L., 1979. Hydrocarbons in southern Taiwan Strait surface sediments. Acta Oceanographica Taiwanica 10, 123-131. 
Jeng, W.L., 1984. Hydrocarbons in marine sediments from off eastern Taiwan. Acta Oceanographica Taiwanica 15, 31-38.

Jeng, W.L., Chen, M.P., 1995. Grain size effect on bound lipids in sediments off northeastern Taiwan. Organic Geochemistry $23,301-310$.

Kao, S.J., Liu, K.K., 1996. Particulate organic carbon export from a subtropical mountainous river (Lanyang Hsi) in Taiwan. Limnology and Oceanography 41, 1749-1757.

Kattner, G., Krause, M., 1989. Seasonal variations of lipids (wax esters, fatty acids and alcohols) in calanoid copepods from the North Sea. Marine Chemistry 26, 261-275.

KEEP-MASS, 1992. Kuroshio Edge Exchange Processes marginal seas study. ROC-Russia Marine Science Collaboration Project.

Keizer, P.D., Dale, J., Gordon Jr., D.C., 1978. Hydrocarbons in surficial sediments from the Scotian Shelf. Geochimica et Cosmochimica Acta 42, 165-172.

Kennicutt, M.C.II, Brooks, J.M., McDonald, T.J., 1991. Origins of hydrocarbons in Bering Sea sediments-I. Aliphatic hydrocarbons and fluorescence. Organic Geochemistry $17,75-83$.

Kolattukudy, P.E., 1970. Plant waxes. Lipids 5, 259-275.

Lee, C., Farrington, J.W., Gagosian, R.B., 1979. Sterol geochemistry of sediments from the western North Atlantic Ocean and adjacent coastal areas. Geochimica et Cosmochimica Acta 43, 35-46.

Lee, C.S., Chung, S.L., SPOT Members, 1998. Southernmost part of the Okinawa Trough (SPOT): an active extension/ collision/subduction area. EOS Transaction of American Geophysical Union 79, W109.

Lin, S., Liu, K.K., Chen, M.P., Chen, P., Chang, F.Y., 1992. Distribution of organic carbon in the KEEP area continental margin sediments. Terrestrial, Atmospheric, and Oceanic Sciences (ROC) 3, 365-378.

Louda, J.W., Baker, E.W., 1984. Perylene occurrence, alkylation and possible sources in deep-ocean sediments. Geochimica et Cosmochimica Acta 48, 1043-1058.

Meyers, P.A., Ishiwatari, R., 1995. Organic matter accumulation records in lake sediments. In: Lerman, A., Imboden, D.M., Gat, J.R. (Eds.), Physics and Chemistry of Lakes. Springer, Berlin, pp. 279-328.

Meyers, P.A., Leenheer, M.J., Eadie, B.J., Maule, S.J., 1984. Organic geochemistry of suspended and settling particulate matter in Lake Michigan. Geochimica et Cosmochimica Acta 48, 443-452.

Pocklington, R., Leonard, J.D., Crewe, N.F., 1991. Sources of organic matter to surficial sediments from the Scotian Shelf and Slope, Canada. Continental Shelf Research 11, 1069-1082.

Prahl, F.G., Carpenter, R., 1983. Polycyclic aromatic hydrocarbon (PAH)-phase associations in Washington coastal sediment. Geochimica et Cosmochimica Acta 47, 1013-1023.

Prahl, F.G., Carpenter, R., 1984. Hydrocarbons in Washington coastal sediments. Estuarine Coastal and Shelf Science 18, 703-720.

Prahl, F.G., Bennett, J.T., Carperter, R., 1980. The early diagenesis of aliphatic hydrocarbons and organic matter in sedimentary particulates from Dabob Bay, Washington. Geochimica et Cosmochimica Acta 44, 1967-1976.

Prahl, F.G., Hayes, J.M., Xie, T.-M., 1992. Diploptene: an indicator of terrigenous organic carbon in Washington coastal sediments. Limnology and Oceanography 37, $1290-1300$.

Rohmer, M., Bouvier-Nave, P., Ourisson, G., 1984. Distribution of hopanoid triterpenes in prokaryotes. Journal of General Microbiology 130, 1137-1150.

Scalan, R.S., Smith, J.E., 1970. An improved measure of the odd-even predominance in the normal alkanes of sediment extracts and petroleum. Geochimica et Cosmochimica Acta 34, 611-620.

Scheuer, P.J., 1973. Chemistry of Marine Natural Products. Academic Press, New York, pp. 61-82.

Shaw, P.M., Johns, R.B., 1985. Organic geochemical studies of a recent Inner Great Barrier Reef sediment-I. Assessment of input sources. Organic Geochemistry 8, 147-156.

Sicre, M.A., Broyelle, I., Lorre, A., Saliot, A., 1993. Sources and transport of particulate hydrocarbons in the meso-tidal Changiiang Estuary. Estuarine Coastal and Shelf Science 37, 557-573.

Smith, D.J., Eglinton, G., Morris, R.J., 1983. The lipid chemistry of an interfacial sediment from the Peru Continental Shelf: fatty acids, alcohols, aliphatic ketones and hydrocarbons. Geochimica et Cosmochimica Acta 47, 2225-2232.

Snedaker, S.C., Glynn, P.W., Rumbold, D.G., Corcoran, E.F., 1995. Distribution of $n$-alkanes in marine samples from southeast Florida. Marine Pollution Bulletin 30, 83-89.

Tang, T.Y., Hsueh, Y., Yang, Y.J., Ma, J.C., 1999. Continental slope flow northeast of Taiwan. Journal of Physical Oceanography 29, 1353-1362.

Thompson, S., Eglinton, G., 1978. The fractionation of a Recent sediment for organic geochemical analysis. Geochimica et Cosmochimica Acta 42, 199-207.

Tulloch, A.P., 1976. Chemistry of waxes of higher plants. In: Kolattukudy, P.E. (Ed.), Chemistry and Biochemistry of Natural Waxes. Elsevier, Amsterdam, pp. 235-287.

Venkatesan, M.I., 1988. Occurrence and possible sources of perylene in marine sediments - a review. Marine Chemistry $25,1-27$.

Venkatesan, M.I., Ruth, E., Steinberg, S., Kaplan, I.R., 1987. Organic geochemistry of sediments from the continental margin off southern New England, USA-part II. Lipids. Marine Chemistry 21, 267-299.

Venkatesan, M.I., Steinberg, S., Kaplan, I.R., 1988. Organic geochemical characterization of sediments from the continental shelf south of New England as an indicator of shelf edge exchange. Continental Shelf Research 8, 905-924.

Volkman, J.K., 1986. A review of sterol markers for marine and terrigenous organic matter. Organic Geochemistry 9, 83-99.

Volkman, J.K., Farrington, J.W., Gagosian, R.B., 1987. Marine and terrigenous lipids in coastal sediments from the Peru upwelling region at $15^{\circ} \mathrm{S}$ : sterols and triterpene alcohols. Organic Geochemistry 11, 463-477. 
Volkman, J.K., Barrett, S.M., Blackburn, S.I., Mansour, M.P., Sikes, E.L., Gelin, F., 1998. Microalgal biomarkers: a review of recent research developments. Organic Geochemistry $29,1163-1179$.

Wakeham, S.G., 1996. Aliphatic and polycyclic aromatic hydrocarbons in Black Sea sediments. Marine Chemistry 53, 187-205.

Wannigama, G.P., Volkman, J.K., Gillan, F.T., Nichols, P.D., Johns, R.B., 1981. A comparison of lipid components of the fresh and dead leaves and pneumatophores of the mangrove Avicennia marina. Phytochemistry 20, 659-666.

Water Resources Bureau, 1998. Hydrological Year Book of Taiwan Republic of China 1997, Ministry of Economic Affairs, Taipei, Taiwan, Republic of China.

Weete, J.D., 1976. Algal and fungal waxes. In: Kolattukudy, P.E. (Ed.), Chemistry and Biochemistry of Natural Waxes. Elsevier, Amsterdam, pp. 392.
Yunker, M.B., Macdonald, R.W., Fowler, B.R., Cretney, W.J., Dallimore, S.R., McLaughlin, F.A., 1991. Geochemistry and fluxes of hydrocarbons to the Beaufort Sea shelf: a multivariate comparison of fluvial inputs and coastal erosion of peat using principal components analysis. Geochimica et Comochimica Acta 55, 255-273.

Yunker, M.B., Macdonald, R.W., Cretney, W.J., Fowler, B.R., McLaughlin, F.A., 1993. Alkane, terpene, and polycyclic aromatic hydrocarbon geochemistry of the Mackenzie River and Mackenzie shelf: riverine contributions to Beaufort sea coastal sediment. Geochimica et Comochimica Acta 57, 3041-3061.

Youngblood, W.W., Blumer, M., Guillard R, .L., Fiore, F., 1971. Saturated and unsaturated hydrocarbons in marine benthic algae. Marine Biology 8, 190-201. 